\title{
Induction of Caspase-3-Like Protease May Mediate Delayed Neuronal Death in the Hippocampus after Transient Cerebral Ischemia
}

\author{
Jun Chen, ${ }^{1}$ Tetsuya Nagayama, ${ }^{1}$ Kunlin Jin, ${ }^{1}$ R. Anne Stetler, ${ }^{1,2}$ Raymond L. Zhu, ${ }^{1}$ Steven H. Graham, ${ }^{1,2}$ and \\ Roger P. Simon 1
}

1Department of Neurology, University of Pittsburgh School of Medicine, Pittsburgh, Pennsylvania 15213, and ${ }^{2}$ Neurology Service, Department of Veterans Affairs Medical Center, Pittsburgh, Pennsylvania 15261

\begin{abstract}
Delayed neuronal death after transient cerebral ischemia may be mediated, in part, by the induction of apoptosis-regulatory gene products. Caspase- 3 is a newly characterized mammalian cysteine protease that promotes cell death during brain development, in neuronal cultures, and in other cell types under many different conditions. To determine whether caspase-3 serves to regulate neuronal death after cerebral ischemia, we have (1) cloned a cDNA encoding the rat brain caspase-3; (2) examined caspase-3 mRNA and protein expression in the brain using in situ hybridization, Northern and Western blot analyses, and double-labeled immunohistochemistry; (3) determined caspase-3-like activity in brain cell extracts; and (4) studied the effect of caspase-3 inhibition on cell survival and DNA fragmentation in the hippocampus in a rat model of transient global ischemia. At 8-72 hr after ischemia, caspase-3 mRNA and protein were induced in the hippocampus and caudate-
\end{abstract}

Transient global ischemia results in delayed neuronal death in selectively vulnerable brain regions such as the hippocampal CA1 sector and caudate-putamen (Pulsinelli et al., 1982). A number of recent studies suggest that cell death in this setting involves apoptosis-an active and genetically controlled cell suicide process. Histological and biochemical characteristics of apoptosis are present in dying neurons after ischemia (MacManus et al., 1993; Kihara et al., 1994; Nitatori et al., 1995), and inhibition of new protein synthesis protects CA1 neurons after ischemia (Goto et al., 1990; Papas et al., 1992). Several apoptosis-regulatory genes are found to be induced in ischemic cells. Bax, a bcl-2 homolog that effects apoptosis, is upregulated in neurons destined to die after global ischemia (Krajewski et al., 1995; Chen et al., 1996), whereas the apoptosis-suppressor gene bcl-2 is expressed in neurons that survive ischemia (Shimazaki et al., 1994; Chen et al., 1997a). Furthermore, bcl-2 overexpression in rodent brain reduces ischemic injury (Martinou et al., 1994; Linnik et al., 1995; Lawrence et al., 1996). Taken together, these observations sug-

Received Feb. 5, 1998; revised April 7, 1998; accepted April 10, 1998.

This work was supported by National Institutes of Health Grants NS 35965 to R.P.S., S.H.G., and J.C., NS 24728 to R.P.S., and NS 36736 to J.C. J.C. was also supported in part by the Competitive Medical Research Fund of the University of Pittsburgh Medical Center. S.H.G. was also supported by the Department of Veterans Affairs Merit Review Program. We thank Dr. David A. Greenberg for critical review and helpful comments on this paper, Jingyun Luan for technical assistance, and Pat Strickler for secretarial support.

Correspondence should be addressed to Dr. Jun Chen, Department of Neurology, S506-Biomedical Science Tower, University of Pittsburgh School of Medicine, Pittsburgh, PA 15213.

Copyright (C) 1998 Society for Neuroscience $\quad 0270-6474 / 98 / 184914-15 \$ 05.00 / 0$ putamen (CPu), accompanied by increased caspase-3-like protease activity. In the hippocampus, caspase-3 mRNA and protein were predominantly increased in degenerating CA1 pyramidal neurons. Proteolytic activation of the caspase-3 precursor was detected in hippocampus and CPu but not in cortex at 4-72 hr after ischemia. Double-label experiments detected DNA fragmentation in the majority of CA1 neurons and selective CPu neurons that overexpressed caspase-3. Furthermore, ventricular infusion of Z-DEVD-FMK, a caspase-3 inhibitor, decreased caspase- 3 activity in the hippocampus and significantly reduced cell death and DNA fragmentation in the CA1 sector up to $7 \mathrm{~d}$ after ischemia. These data strongly suggest that caspase-3 activity contributes to delayed neuronal death after transient ischemia.

Key words: cerebral ischemia; caspase-3; apoptosis; cysteine protease; neuronal death; neuron

gest that endogenously induced apoptosis-regulatory genes may play a role in determining the fate of ischemic neurons.

The interleukin- $1 \beta$-converting enzyme (ICE) family of cysteine proteases, now referred to as caspases, is another group of apoptosis-regulatory genes that may play a role in ischemic brain injury (Bredesen, 1995). The ICE family, consisting of at least 11 members (caspases-1-11), represents mammalian homologs of ced-3, an essential cell death gene in Caenorhabditis elegans (Yuan et al., 1993; Fernandes-Alnemri et al., 1994; Xue et al., 1996). When overexpressed, the caspases trigger apoptosis in cultured cells (Miura et al., 1993). Among the identified caspases, caspase-3 (also termed cpp32, Yama, or Apopain) exhibits the highest sequence homology to ced-3 (Tewari et al., 1995). Caspase- 3 is a potent effector of apoptosis triggered via several different pathways in a variety of mammalian cell types (for review, see Alnemri et al., 1996). Caspase-3 promotes neuronal death during brain development (Kuida et al., 1996). In neuronal cultures, induction of caspase-3-like protease promotes apoptosis induced by withdrawal of trophic support, $\mathrm{K}^{+}$deprivation, or glutamate excitotoxicity (Deshmukh et al., 1996; Schulz et al., 1996; Du et al., 1997; Keane et al., 1997; Ni et al., 1997). Moreover, inhibition of ICE- or caspase-3-like protease provides protection in rodent brains subjected to focal ischemia or direct excitotoxic insults (Hara et al., 1997) or to traumatic brain injury (Yakovlev et al., 1997). Thus, caspase-3 and related caspases could be important neuronal death effectors in the brain under certain pathological conditions.

We, therefore, characterized the regional and temporal profiles 
of caspase-3 gene expression in the rat brain at both mRNA and protein levels after transient global ischemia. Then we determined whether caspase-3-like protease activity is altered in the brain after ischemia and how the altered enzymatic activity correlates with regional vulnerability to ischemia. Lastly, by inhibiting caspase-3-like activity in the hippocampus in vivo, we investigated the role of induction of this important cell death gene in determining the fate of ischemic neurons.

\section{MATERIALS AND METHODS}

\section{Animal model of transient global ischemia}

Experiments were performed on a total of 238 male Sprague Dawley rats weighing 300-350 gm (Hilltop Sprague Dawley, Scottdale, PA). Transient global ischemia (15 min) was induced in isoflurane-anesthetized rats using a previously described method (Pulsinelli et al., 1982), with modifications (Chen et al., 1996). Blood pressure, blood gases, and blood glucose concentration were monitored and maintained in the normal range throughout the experiments. Rectal temperature was continuously monitored and kept at $37-37.5^{\circ} \mathrm{C}$ using a heating pad and a temperatureregulated heating lamp. Brain temperature was monitored by a $29 \mathrm{ga}$ thermocouple implanted in the left striatum and kept at $36.4 \pm 0.2^{\circ} \mathrm{C}$ during ischemia and at $37-37.5^{\circ} \mathrm{C}$ thereafter. An electroencephalogram (EEG) was monitored in all animals to ensure isoelectricity within $10 \mathrm{sec}$ after carotid artery occlusion. A sham operation was performed in additional animals using the same anesthesia and surgical exposure procedures except that the arteries were not occluded; these brains were used as nonischemic controls.

\section{cDNA cloning}

Construction of a cDNA library. Hippocampi were dissected from rat brains subjected to $15 \mathrm{~min}$ of ischemia followed by 8,24 , or $72 \mathrm{hr}$ of reperfusion (three brains per time point). Polyadenylated mRNAs were isolated from the hippocampi using a fast track mRNA isolation kit (Invitrogen, San Diego, CA) and were used as templates for cDNA synthesis. An ischemic brain cDNA library was constructed using a SuperScript plasmid system for cDNA synthesis and a plasmid cloning kit according to the manufacturer's instructions (Gibco BRL, Gaithersburg, $\mathrm{MD})$. In brief, first-strand cDNA was synthesized using the oligo-dT $\mathrm{T}_{12}$ Not I primer adapter and SuperScript II reverse transcriptase (RT); second-strand synthesis was catalyzed by Escherichia coli DNA polymerase I in combination with $E$. coli RNase $\mathrm{H}$ and $E$. coli DNA ligase. Double-stranded DNA was restricted with NotI and SalI, selected on a cDNA size fraction column to include molecules of $>500 \mathrm{bp}$, ligated into plasmid pSPORT 1, and transformed into E. coli DH5a. The constructed cDNA library was examined by the color-selection method using isopropyl-1-thio- $\beta$-D-galactoside-X-gal and titer measurement after amplification. The titer of the amplified library was $10^{11} \mathrm{pfu} / \mathrm{ml}$.

Isolation of a cDNA encoding caspase-3. In preliminary studies, a $345 \mathrm{bp}$ cDNA fragment encoding the rat caspase- 3 was generated by RT-PCR using primers designed according to the conserved sequences in human and mouse caspase-3 (Fernandes-Alnemri et al., 1994; Tewari et al., 1995). This cDNA fragment was labeled with $\left[{ }^{32} \mathrm{P}\right] \mathrm{dATP}$ using random primers and SuperScript II RT (Gibco BRL) and then was purified using a NucTrap probe purification column (Stratagene, La Jolla, CA). To obtain a cDNA containing the open reading frame encoding the caspase- 3 protein, we used the labeled cDNA probe to screen the ischemic cDNA library. Colonies of the cDNA library were plated onto 137 $\mathrm{mm}$ filters, denatured, and neutralized. The filters were hybridized in $50 \%$ formamide-containing $5 \times$ saline-sodium phosphate-EDTA buffer, $1 \%$ SDS, $2 \times$ Denhardt's solution, and $5 \%$ dextran sulfate with the ${ }^{32} \mathrm{P}$-labeled caspase- $3 \mathrm{cDNA}$ probe $\left(5 \times 10^{6} \mathrm{cpm} / \mathrm{ml}\right)$ at $42^{\circ} \mathrm{C}$ for $18 \mathrm{hr}$. The resulting positive clones were sequenced on both strands using the dideoxy chain termination technique (Sequenase II; United States Biochemicals, Cleveland, $\mathrm{OH})$. Sequence analysis was performed using MacVector software (International Biotechnologies, New Haven, CT) and aligned using the BLAST program (www.ncbi.nlm.nih.gov).

In vitro transcription and translation. To confirm that the cDNA contains the full open reading frame, we performed in vitro transcription and translation to detect its protein product. Transcription was performed using an RNA transcription kit according to the manufacturer's instructions (Stratagene). In brief, $1 \mu \mathrm{g}$ of linearized plasmid DNA was incubated at $37^{\circ} \mathrm{C}$ for $1 \mathrm{hr}$ in a mixture containing $40 \mathrm{~mm}$ Tris- $\mathrm{HCl}, \mathrm{pH} 8.0$, $8 \mathrm{mM} \mathrm{MgCl}_{2}$, 2 mM spermidine, $50 \mathrm{~mm} \mathrm{NaCl}, 40 \mathrm{~mm}$ DTT, $2 \mathrm{~mm}$ dNTP, and $10 \mathrm{U}$ of T7 RNA polymerase. After DNA digestion using $200 \mathrm{U}$ of RNase-free DNase (Promega, Madison, WI), RNA was extracted from the reaction mixture with phenol and chloroform followed by precipitation with 0.5 volume of ammonium acetate and 2.5 volumes of ethanol. In vitro translation was then performed at $30^{\circ} \mathrm{C}$ for $1 \mathrm{hr}$ in a reaction system containing $100 \mathrm{ng}$ of extracted RNA, $2 \mu \mathrm{l}$ of translation reaction mixture (Boehringer Mannheim, Indianapolis, IN), $10 \mu \mathrm{l}$ of rabbit reticulocyte lysate, $100 \mathrm{~mm}$ potassium acetate, and $1 \mathrm{~mm}$ magnesium acetate in the presence of $\left[{ }^{35} \mathrm{~S}\right]$ methionine ( $>800 \mathrm{Ci} / \mathrm{mmol}$; NEN, Boston, MA). Translated protein was electrophoresed in a $12 \%$ SDS-polyacrylamide gel and detected by autoradiography.

\section{Northern blot analysis}

Total RNA was isolated from the hippocampi of brains subjected to 15 min of ischemia followed by 8 and 24 hr of reperfusion $(n=3$ per time point) or brains $24 \mathrm{hr}$ after sham operation $(n=3)$ as described previously (Chen et al., 1996). RNA was electrophoresed on a $1.0 \%$ agarose-formaldehyde gel, blotted onto Hybond-N membrane (Amersham, Arlington Heights, IL), and prehybridized for $2 \mathrm{hr}$ at $42^{\circ} \mathrm{C}$. The membranes were subsequently hybridized with the rat caspase- 3 cDNA probe for $24 \mathrm{hr}$ at $42^{\circ} \mathrm{C}$. The ${ }^{32} \mathrm{P}$-labeled cDNA probe was prepared using the random primer method. cDNA inserts were released from the plasmid with restriction enzyme digestion and purified using the Gene Clean kit (BIO 101, La Jolla, CA). Approximately $25 \mathrm{ng}$ of cDNA inserts was dissolved in $20 \mu \mathrm{l}$ of distilled water in a microcentrifuge tube, heated for $5 \mathrm{~min}$ in a boiling water bath, and then immediately cooled on ice. Two microliters of a reaction mixture containing $0.5 \mathrm{~mm}$ each of dATP, dTTP, and dGTP; $10 \mu \mathrm{l}$ of random primer buffer (Gibco BRL); $50 \mu \mathrm{Ci}$ of $\left[\alpha^{-32} \mathrm{P}\right] \mathrm{dCTP}$; and $3 \mathrm{U}$ of the large fragment of DNA polymerase I were added to the cDNA preparation and incubated at room temperature for $1 \mathrm{hr}$. The labeled probe was purified using the NucTrap probe purification column (Stratagene). Labeling efficiency of the probe was determined by measuring percentage incorporation of the radioisotope. After the hybridization and washing procedures, autoradiography was performed at $-80^{\circ} \mathrm{C}$ overnight with an intensifying screen. Autoradiograph signals were quantified by a gel densitometric scanning program using the Microcomputer Imaging Device (MCID) image analysis system. To control for variation in the amount of total RNA in different samples, we stripped off the original probe in a solution containing $0.1 \times \mathrm{SSC}$ and $0.5 \% \mathrm{SDS}$ at $100^{\circ} \mathrm{C}$ for $15 \mathrm{~min}$. The blot was rehybridized with an oligodeoxynucleotide probe (5'-ACGGTATCTGATCGTCTTCGAACC - $3^{\prime}$ ) corresponding to $18 \mathrm{~S}$ RNA. All densitometric values for caspase- 3 were normalized to values for $18 \mathrm{~S}$ RNA obtained on the same lane.

\section{In situ hybridization}

The ${ }^{35}$ S-labeled single-stranded RNA probe was prepared from plasmids containing the rat caspase- 3 cDNA inserts. For the preparation of the antisense probe, the plasmid was linearized by XhoI digestion. A product complementary to the rat caspase-3 mRNA was transcribed by the T3 RNA polymerase in the presence of $125 \mu \mathrm{Ci}$ of ${ }^{35} \mathrm{~S}$-UTP (NEN) using an in vitro transcription kit according to the manufacturer's instructions (Stratagene). For the sense probe, the plasmid was linearized by PstI and subsequently transcribed using the T7 RNA polymerase (Stratagene). The transcription reaction was performed for $45 \mathrm{~min}$ at room temperature, and the cDNA template was then digested for $10 \mathrm{~min}$ at $37^{\circ} \mathrm{C}$ using DNase I $(10 \mathrm{U})$ in the presence of tRNA $(20 \mu \mathrm{g})$. The RNA probe was extracted from the reaction mixture using phenol and chloroform followed by precipitation with 0.5 volume of ammonium acetate and 2.5 volumes of ethanol. After centrifugation, the pellet was rinsed with cold graded ethanol, air dried, and resuspended in $50 \mu \mathrm{l}$ of $10 \mathrm{~mm}$ DTT. Labeling efficiency of the probe was determined by measuring percentage incorporation of the radioisotope. Frozen sections from ischemic, sham-operated, or naive control brains were prepared as described previously (Chen et al., 1996). Coronal sections at the levels of the dorsal hippocampus (anteroposterior, -3.5 to $-4.0 \mathrm{~mm}$ from the bregma) were selected and processed for in situ hybridization. Neuronal degeneration at these levels after $15 \mathrm{~min}$ of global ischemia has been characterized and described elsewhere (Chen et al., 1996, 1997a, 1998). The sections were treated under RNase-free conditions with $4 \%$ paraformaldehyde in PBS for $20 \mathrm{~min}$, rinsed twice for $5 \mathrm{~min}$ in PBS, and then acetylated twice for 5 min with acetic anhydride in $0.1 \mathrm{M}$ triethanolamine-HCl, $\mathrm{pH} 7.5$. After washing in PBS for $5 \mathrm{~min}$ and saline for $5 \mathrm{~min}$, the sections were dehydrated in graded ethanol and air-dried. The sections were hybridized with the labeled RNA probe $\left(1 \times 10^{7} \mathrm{cpm} / \mathrm{ml}\right)$ in a hybridization 
cocktail for $18 \mathrm{hr}$ at $55^{\circ} \mathrm{C}$. The slices were then washed twice for $10 \mathrm{~min}$ in $2 \times$ SSC (300 mm sodium chloride and $30 \mathrm{~mm}$ sodium citrate, $\mathrm{pH} 7.4$ ), once for $2 \mathrm{hr}$ in $0.1 \times \mathrm{SSC}$ at $50^{\circ} \mathrm{C}$, and then twice for $10 \mathrm{~min}$ in $0.5 \times \mathrm{SSC}$ at room temperature. They were then dehydrated, air dried, and autoradiographed onto Kodak SB-5 film for 3 weeks. Control and ischemic brain slides were processed together and developed on the same film. Relative changes in regional mRNA expression were semiquantitated using the MCID system (St. Catharine's, Ontario, Canada) as described previously (Chen et al., 1998). Cellular localization of the labeled mRNA was evaluated by coating slides with Kodak NTB-2 emulsion. Sections were exposed at $4^{\circ} \mathrm{C}$ for 5 weeks, developed in Kodak D-19, and counterstained with cresyl violet.

\section{Western blot analysis}

Animals were killed at 4, 8, 24, or $72 \mathrm{hr}$ after $15 \mathrm{~min}$ of ischemia or 24 hr after sham operation ( $n=4$ per experimental condition). The hippocampus, striatum, and cortex were separately dissected, homogenized, and lysed. The lysates were cleared by centrif ugation at $14,000 \times g$ for 30 $\min$ at $4^{\circ} \mathrm{C}$. The protein was denatured in SDS gel-loading buffer $(100$ mM Tris- $\mathrm{HCl}, 200 \mathrm{~mm}$ dithiothreitol, $4 \%$ SDS, $0.2 \%$ bromophenol blue, and $20 \%$ glycerol) at $100^{\circ} \mathrm{C}$ for $6 \mathrm{~min}$ and then separated on $12 \%$ SDS-polyacrylamide gels (40 $\mu \mathrm{g}$ per sample). Immunoblotting was performed as described previously (Chen et al., 1996), using a chemiluminescent detection system (Clontech, Palo Alto, CA). The antibody used to detect the caspase-3 protein was a custom-made rabbit polyclonal antibody (Biosynthesis, Dallas, TX) raised against the deduced C-terminal sequence $\left(\mathrm{NH}_{2}\right.$-QACRGTELDCGIETD-COOH) of the rat caspase-3 larger active form p17. The working dilution for caspase-3 antibody in the present study was 1:2000. The synthesized peptide for immunization was also used in preabsorption experiments to confirm the specificity of the detected immunoreactivity. This was done by incubating the peptide $(5 \mu \mathrm{g} / \mathrm{ml})$ with the primary antibody for $30 \mathrm{~min}$ at $37^{\circ} \mathrm{C}$ before the immunoblotting was performed. For immunoblotting to detect poly(ADP-ribose) polymerase (PARP), a monoclonal antibody against the C-terminal part of the DNA binding domain of PARP was used at a working dilution of 1:5000, as suggested by the manufacturer (Biomol, Plymouth Meeting, PA). A purified bovine PARP protein was used in preabsorption experiments to confirm the specificity of PARP immunoreactivity. Immunoreactivity for caspase-3 or PARP on each individual lane of the blots was quantified by a gel densitometric scanning program using the MCID image analysis system.

\section{Immunohistochemistry}

Animals were anesthetized with $8 \%$ chloral hydrate at $4,8,24$, or $72 \mathrm{hr}$ after $15 \mathrm{~min}$ of ischemia or $24 \mathrm{hr}$ after sham operation $(n=4$ per time point). They were then perfused with $200 \mathrm{ml}$ of heparinized $0.9 \%$ saline followed by $500 \mathrm{ml}$ of $4 \%$ paraformaldehyde in $0.1 \mathrm{M}$ PBS, pH 7.4. The brains were removed, immersed in $4 \%$ paraformaldehyde for $5 \mathrm{~d}$, and processed for paraffin embedding and cutting ( $6 \mu \mathrm{m}$ thick) on a rotary microtome. Coronal sections at the levels of dorsal hippocampus and midcaudate (anteroposterior, $+0.2 \mathrm{~mm}$ from the bregma) were selected and processed for immunohistochemical staining. The sections were deparaffinized in xylene, rehydrated through graded ethanol, and pretreated with protease $\mathrm{K}(10 \mu \mathrm{g} / \mathrm{ml}$ for $10 \mathrm{~min})$. After three $10 \mathrm{~min}$ washes in PBS, the sections were microwaved in sodium citrate buffer, $\mathrm{pH}$ 6.0, for $5 \mathrm{~min}$ before immunostaining. Immunohistochemical staining for caspase-3 was performed using the same antibody used for Western blot analysis. Briefly, after the preblocking step using the rabbit preimmunizing serum, sections were incubated overnight at room temperature in the primary antibody diluted 1:1000 in PBS, $\mathrm{pH} 7.4$, containing $2 \%$ goat serum, $0.2 \%$ Triton X-100, bovine serum albumin $(5 \mathrm{mg} / \mathrm{ml})$, and $0.2 \%$ glycine. Sections were washed in PBS three times for 10 min each and then incubated for $1 \mathrm{hr}$ at room temperature at a 1:2500 dilution with goat anti-rabbit Cy3.18 immunoconjugate (Jackson ImmunoResearch, West Grove, PA). Sections were then washed in PBS four times for 15 min each on a orbital shaker (model 361; Fisher Scientific, Houston, TX), mounted in gelvatol, and coverslipped. A Zeiss light microscope equipped for epifluorescent illumination was used for observation. For the assessment of nonspecific immunostaining, alternating sections from each experimental condition were incubated without the primary antibody or, in some cases, with antibody that was preabsorbed with the synthetic caspase-3 peptide $(8 \mu \mathrm{g} / \mathrm{ml})$ for $30 \mathrm{~min}$ at room temperature before immunohistochemistry. Immunoreactivity was compared in sections from animals killed $24 \mathrm{hr}$ after ischemia, with or without preabsorption of the primary antibody.

\section{Detection of DNA fragmentation}

In situ detection of DNA fragmentation in brain cells after ischemia or after sham operation was performed using terminal deoxynucleotidyl transferase-mediated biotin-dUTP nick-end labeling (TUNEL) as described previously by Gavrieli et al. (1992), with modifications (Chen et al., 1997b). For double-label experiments, paraffin-imbedded sections, at the levels of dorsal hippocampus and midcaudate, obtained 24 and $72 \mathrm{hr}$ after ischemia and $24 \mathrm{hr}$ after sham operation $(n=4$ per experimental condition) were used. The sections were pretreated as described above and then incubated at $37^{\circ} \mathrm{C}$ for $90 \mathrm{~min}$ in $1 \times$ terminal deoxynucleotidyl transferase (TdT) buffer containing $100 \mathrm{U} / \mathrm{ml}$ TdT and $20 \mathrm{nmol} / \mathrm{ml}$ biotin-conjugated 16-dUTP (Boehringer Mannheim). After three washes in PBS (10 $\mathrm{min} / \mathrm{wash})$, the sections were incubated at room temperature for 15 min in fluorescein-avidin D cell sorting (DCS) (cell sorting grade; Vector Laboratories, Burlingame, CA) diluted in PBS at $8 \mu \mathrm{g} / \mathrm{ml}$. Sections were then processed for caspase-3 immunohistochemistry as described above, and all steps were performed in the dark. Sections were examined by fluorescence microscopy using excitation/emission wavelengths of 550/565 nm (red) and 495/515 nm (green-yellow) for caspase-3 and TUNEL, respectively.

\section{Activities of caspase-3- and ICE-like proteases}

Measurement of caspase-3- and ICE-like protease activity in brain cell extracts was performed as originally described (Enari et al., 1996) with the slight modifications suggested by Clontech. The animals were anesthetized using $8 \%$ chloral hydrate and decapitated. Brains were quickly removed. Tissues were dissected separately from the hippocampus, striatum, cortex, or cerebellum of brains at 1, 4, 8, 24, and $72 \mathrm{hr}$ after ischemia, at $24 \mathrm{hr}$ after sham operation, or from naive animals $(n=4-5$ per experimental condition). Protein extracts were prepared on ice by Dounce homogenization of tissues in a lysis buffer containing $25 \mathrm{~mm}$ HEPES, 5 mm EDTA, 1 mM EGTA, $5 \mathrm{~mm} \mathrm{MgCl}_{2}$, $5 \mathrm{~mm}$ DTT, and 10 $\mu \mathrm{g} / \mathrm{ml}$ each of pepstatin, leupeptin, aprotinin, and PMSF (Sigma, St. Louis, MO). Cell lysate was centrifuged at 15,000 rpm for $10 \mathrm{~min}$, and the supernatant was used for the enzymatic assay. One hundred micrograms of the extracted proteins were incubated for $1 \mathrm{hr}$ at $37^{\circ} \mathrm{C}$ with the reaction buffer (25 mM HEPES, pH 7.5, $10 \%$ sucrose, $0.1 \%$ 3-[(3cholamidopropyl)dimethylammonio]-1-propane sulfonate, $5 \mathrm{~mm}$ DTT, and $5 \mathrm{~mm}$ EDTA) in a total volume of $150 \mu \mathrm{l}$ containing $25 \mu \mathrm{M}$ colorimetric peptide substrate (Biomol). The following two substrates were used for the assays: acetyl-Asp-Glu-Val-Asp-p-nitroanilide (Ac-DEVD$p$ NA) for caspase-3-like protease activity and acetyl-Tyr-Val-Ala-Asp$p$-nitroanilide (Ac-YVAD-pNA) for ICE-like protease activity. Enzymecatalyzed release of $p$-nitroanilide was measured at $405 \mathrm{~nm}$ in a microtiter plate reader (Molecular Devices, Palo Alto, CA). One unit of protease activity corresponds to the caspase-like activity that cleaves 1 pmol of $p$ NA per minute at $37^{\circ} \mathrm{C}$ at saturating substrate concentrations. In certain experiments, the extracted protein sample was diluted in the reaction buffer and first incubated with inhibitors for caspase-3 (DEVD$\mathrm{CHO}$ ) and ICE (YVAD-CHO) at room temperature for $30 \mathrm{~min}$ (Lazebnik et al., 1994; Nicholson et al., 1995).

\section{In vivo inhibition of caspase-3-like protease}

$N$-Benzyloxycarbonyl-Asp(OMe)-Glu(OMe)-Val-Asp-(OMe)-fluoro-methylketone (Z-DEVD-FMK) (Enzyme Systems Products, Livermore, CA), a peptide methylketone caspase-3 inhibitor (Nicholson et al., 1995; Rodriguez et al., 1996), was dissolved in DMSO at a concentration of $18.75 \mathrm{mg} / \mathrm{ml}$ and further diluted $1: 25,1: 75$, or $1: 225$ in mock CSF. Peptide infusions were performed using a $10 \mu \mathrm{l}$ Hamilton syringe (Hamilton, Reno, NV) through a preimplanted 21 ga cannula in the left ventricle (from the bregma: anteroposterior, $-0.8 \mathrm{~mm}$; lateral, $1.5 \mathrm{~mm}$; depth, $3.5 \mathrm{~mm}$ ). Each animal received three ventricular inf usions of $2 \mu \mathrm{l}$ each over a $5 \mathrm{~min}$ time period $30 \mathrm{~min}$ before ischemia and 2 and $24 \mathrm{hr}$ after ischemia, except as indicated otherwise. The resulting peptide doses for infusion treatment were $0.057 \mu \mathrm{g} \times 3,1.5 \mu \mathrm{g} \times 3,0.5 \mu \mathrm{g} \times 3$, and $0.167 \mu \mathrm{g} \times 3$ per animal. Inf usions of diluted DMSO $(0.04 \%)$ served as vehicle controls. All treatments were assigned to animals in a randomized and blinded manner. Brain and rectal temperatures were monitored in all animals before, during, and up to $2 \mathrm{hr}$ after ischemia. The rectal temperature was also measured at 24,48 , and $72 \mathrm{hr}$ after ischemia.

The doses of Z-DEVD-FMK used in the present study were suggested by the focal ischemia studies of others (Hara et al., 1997) and determined by a series of experiments in which the effectiveness of this peptide to inhibit caspase-3 activity in the hippocampus after ischemia was evalu- 
A

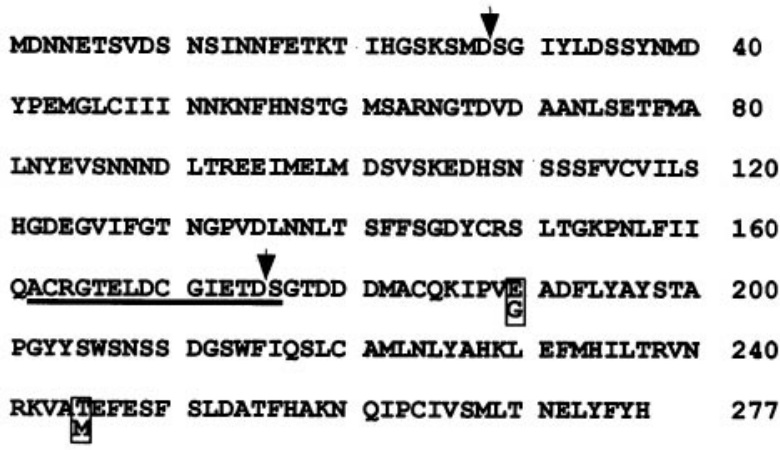

B

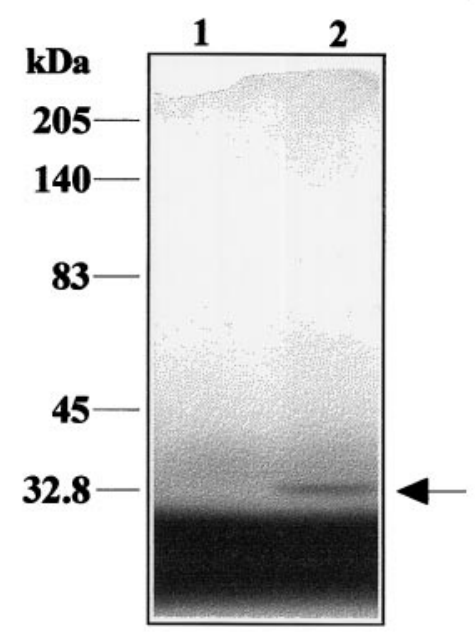

C

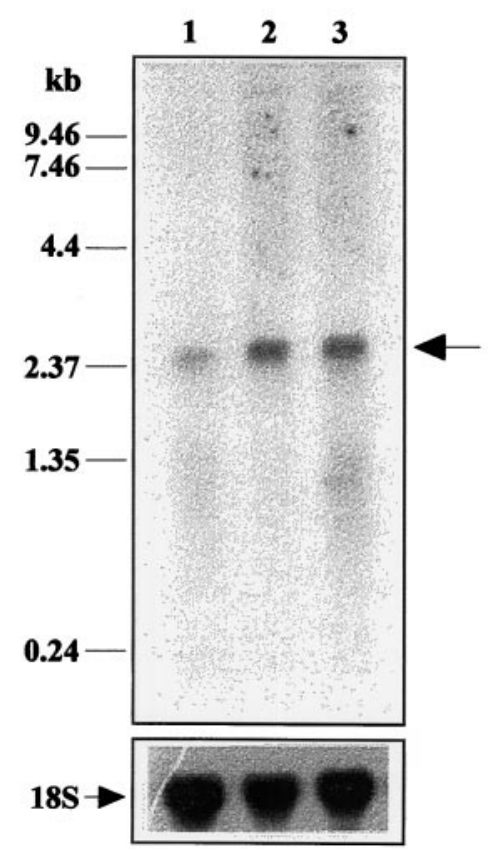

Figure 1. A, Deduced amino acid sequence of rat brain caspase-3 from the cDNA clone. This sequence shares $84.1 \%$ identity with the human cpp32 $\beta$ (Fernandes-Alnemri et al., 1994) and 99.3\% with the rat brain IRP (Ni et al., 1997). The boxes mark the different amino acids between caspase- 3 and the rat brain IRP. Arrowheads indicate the known proen- ated (see Results). For the measurement of caspase-3-like protease activity in peptide- or vehicle-infused brains, the brains were quickly removed $48 \mathrm{hr}$ after ischemia and processed for the enzyme assay as described above.

For histological outcome experiments, rats were killed at 3 or $7 \mathrm{~d}$ after ischemia. Their brains were perfused and paraffin-imbedded, and $6 \mu \mathrm{m}$ sections were cut. Coronal sections at the level of the dorsal hippocampus (anteroposterior, $-4.0 \mathrm{~mm}$ from the bregma) were selected and stained with cresyl violet. Adjacent brain sections were processed for TUNEL staining using the method described above, except that the sections were pretreated with $1 \% \mathrm{H}_{2} \mathrm{O}_{2}$ for $15 \mathrm{~min}$ to quench endogenous peroxidase before incubation in TdT buffer, and the biotin-16-dUTP tailing was detected using the horseradish-streptavidin-peroxidase method (Chen et al., 1997b). Sections were examined by two investigators who were blinded to the experimental conditions. Surviving hippocampal CA1 neurons (showing normal morphology by cresyl violet staining) and cells containing DNA fragmentation (TUNEL positive) were quantified with the assistance of a computerized scanning program (MCID; St. Catharine's).

To determine the potential role of the ICE-like protease in ischemic cell death, we subjected additional rats to ventricle infusion of the ICE inhibitor $N$-benzyloxycarbonyl-Tyr-Val-Ala-Asp(OMe)- $\mathrm{CH}_{2} \mathrm{~F}$ (Z-YVADFMK) (Enzyme Systems Products) before and after ischemia using the same protocol described for Z-DEVD-FMK. Rats received either Z-YVAD-FMK at $0.5 \mu \mathrm{g} \times 3$ or $1.5 \mu \mathrm{g} \times 3$ or the same volume of $0.04 \%$ DMSO ( $n=6$ per group). Three days after ischemia, the brains of these rats were processed for cresyl violet staining, TUNEL staining, and subsequent cell counting in the hippocampal CA1 sector.

\section{Data analysis}

All data are reported as mean \pm SEM. Comparisons of caspase- 3 mRNA expression, caspase-3 protein expression, caspase-3 activity, ICE-like activity, CA1 cell survival, or TUNEL-positive cells at different durations of reperfusion with or without inhibitor treatment versus sham controls were made using ANOVA and post hoc Fisher's PLSD tests. A level of $p<0.05$ was considered statistically significant.

\section{RESULTS}

\section{cDNA cloning of rat brain caspase-3}

To characterize the expression pattern of the caspase- 3 gene in the brain after ischemia, we cloned a cDNA containing the entire open reading frame of caspase- 3 from the ischemic brain cDNA library. Sequence analysis revealed that this cDNA encodes an open reading frame of 277 amino acids (Fig. $1 A$ ). The deduced amino acid sequence had 84.1 and $92.1 \%$ identity to the published sequences of human and mouse cpp32 $\beta$ (Fernandes-Alnemri et al., 1994; Tewari et al., 1995), respectively. The positions of several predicted functional residues were also identical to those of human and mouse cpp32 $\beta$, including the two aspartic acid residues (28 and 175 ) predicted to be the cleavage sites, the three residues required for substrate binding (Arg64, His108, and Arg207), and the QACRG motif responsible for binding of the protease to the aspartic acid residues in the substrate cleavage sites (Nicholson et al., 1995; Juan et al., 1996). After the comple-

\section{$\leftarrow$}

zyme cleavage sites for caspase-3 (Asp28-Ser29 and Asp175-Ser176) that yield the p17 and p12 active forms. The peptide sequence used to raise the caspase- 3 antibody is underlined. $B$, SDS-PAGE analysis of extract of in vitro translation assay product from caspase-3 cDNA. Lane 1, Negative control. cRNA was omitted from the assay. Lane 2, Translation product (arrow) from the caspase-3 cDNA. $C$, Northern blot analysis of caspase-3 mRNA in the hippocampus after sham operation (lane 1) or 8 hr (lane 2) or $24 \mathrm{hr}$ (lane 3) after ischemia. Total RNA was isolated from the hippocampi (three brains per time point) and electrophoresed through a $1 \%$ agarose-formaldehyde gel $(20 \mu \mathrm{g}$ of RNA per lane). The only transcription species resulting from hybridizing with the caspase-3 cDNA probe is $\sim 2.6-2.7 \mathrm{~kb}$ (arrow), consistent with the predicted molecular size of rat caspase-3 mRNA. Bottom, The same blot hybridized with the 18S RNA probe as a control for sample loading. 
A
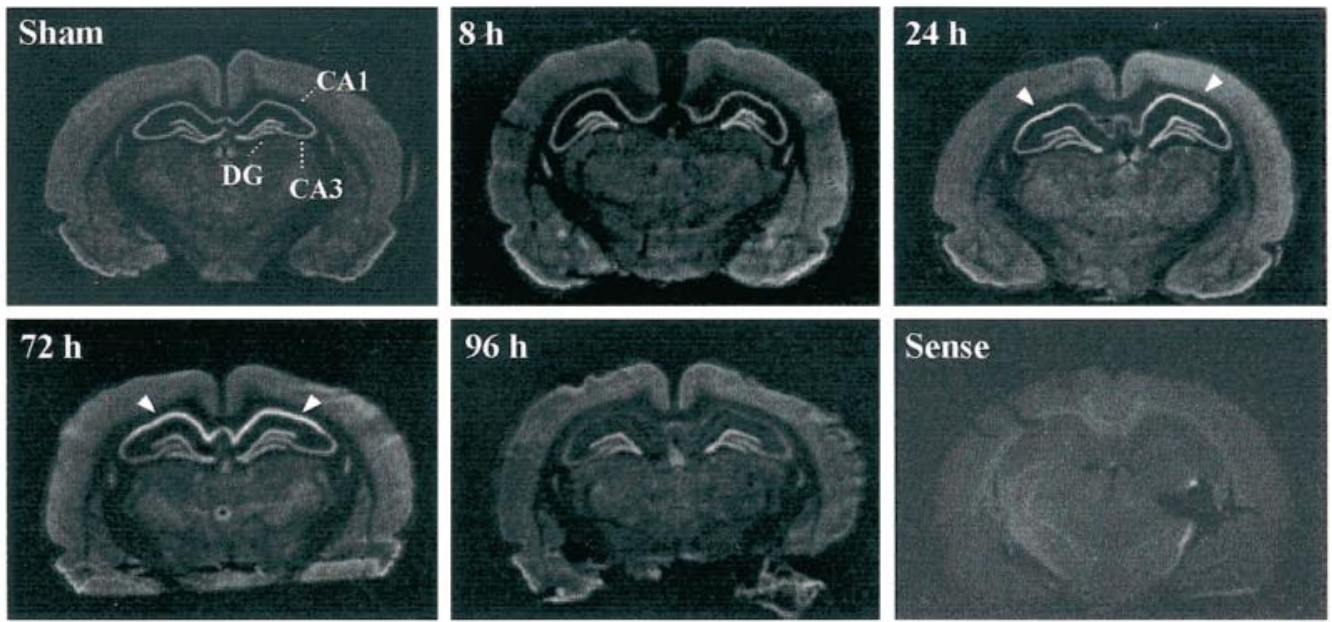

\section{B}
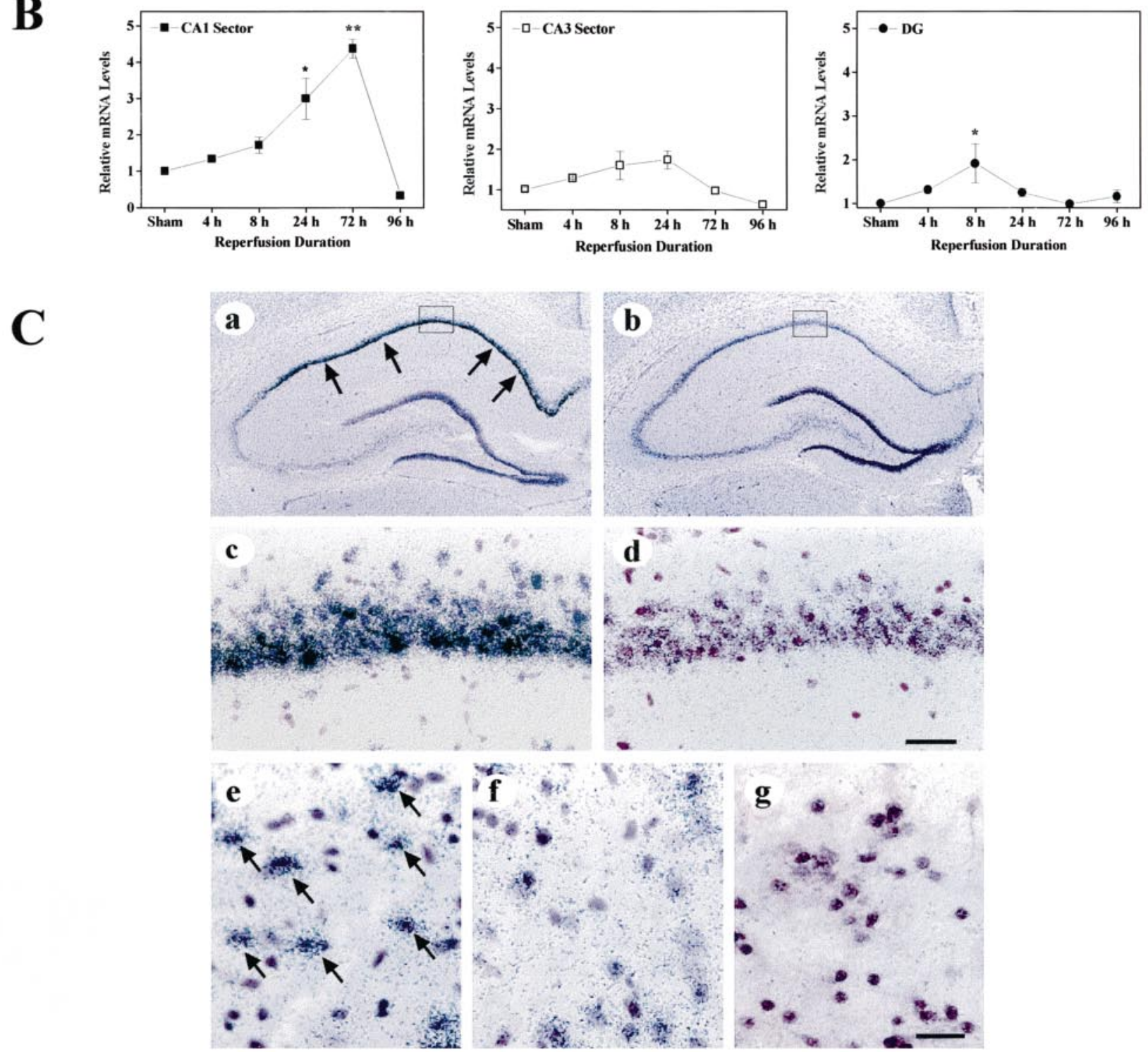

Figure 2. Caspase-3 in situ hybridization. $A$, Representative autoradiograms through the level of dorsal hippocampus in a sham-operated brain and in brains at $8,24,72$, and $96 \mathrm{hr}$ after $15 \mathrm{~min}$ of global ischemia. Caspase-3 mRNA is slightly increased in the dentate gyrus $(D G)$ granule cell layer 8 hr after ischemia but markedly increased in the hippocampal CA1 sector at 24 and $72 \mathrm{hr}$ after ischemia (arrowheads). A section (24 hr after ischemia; Sense) hybridized with the sense cDNA probe results in only background signals. B, Relative caspase-3 mRNA changes in the (Figure legend continues) 
tion of this work, two cDNA sequences encoding the rat caspase-3 homologs were published. One clone, obtained from a rat brain cDNA library and referred to as interleukin-converting enzymerelated protease (IRP) (Ni et al., 1997), was $99.3 \%$ identical to our amino acid sequence. The other clone (cpp32 $\beta)$, cloned from a rat colon cDNA library (Juan et al., 1996), was identical to our sequence at both nucleotide and amino acid levels. Thus, caspase-3 seems to be highly conserved across species and, within a species, across different organs.

Using the cloned cDNA as a template, we found that the in vitro transcription and translation assay produced a protein at $\sim 32$ $\mathrm{kDa}($ Fig. $1 B$ ), the predicted size for caspase-3.

\section{Evidence of caspase-3 gene induction after ischemia}

Previous studies suggest that expression of caspase-3 mRNA and protein is retained in most adult tissues (Juan et al., 1996; Krajewska et al., 1997; Ni et al., 1997). In the present study, we have examined the expression of caspase-3 at both mRNA and protein levels in normal and ischemic brains, focusing on regions such as the hippocampus and caudate-putamen where cells are particularly vulnerable to transient global ischemia. Using Northern blot analysis, we detected caspase-3 mRNA $(\sim 2.6-2.7 \mathrm{~kb})$ in all samples tested (Fig. 1C). Although caspase-3 mRNA was readily detected in the normal hippocampus, the levels were increased at $8 \mathrm{hr}$ (1.8-fold) and $24 \mathrm{hr}$ (2.3-fold) after $15 \mathrm{~min}$ of ischemia.

As shown in Figure $2 A-C$, the cellular distribution of the mRNA was examined further using in situ hybridization in nonischemic brains and in brains 4, 8, 24, 72, or $96 \mathrm{hr}$ after ischemia ( $n=3$ per time point). Consistent with the findings in Northern blots, basal expression of caspase- 3 mRNA was readily detectable in the whole hippocampal formation, including pyramidal neurons in the CA1-CA3 sectors and granule cells in the dentate gyrus (Fig. 2A). Low levels of basal expression were also present in medium-sized neurons in the caudate-putamen and thalamus and in large- and medium-sized neurons in the cortex. Eight hours after ischemia, significantly increased caspase-3 mRNA was first detected in the dentate granule cells (Fig. $2 B$ ). It subsided to near control levels in this region thereafter. In the CA1 sector, a slight increase in caspase-3 mRNA was first seen at $8 \mathrm{hr}$. The signals were markedly increased in this region at 24 and $72 \mathrm{hr}$ after ischemia. Examination of emulsion-coated sections revealed that many neurons in the thalamus and dorsolateral putamen also showed increased caspase-3 mRNA signal at 24-72 hr after ischemia. In the cortex, however, only a few scattered shrunken neurons in layers III-V showed increased mRNA. In control experiments, sections hybridized with the sense cDNA probe showed a low-level background signal that was homogeneous throughout the brain sections (Fig. $2 A, C$ ).

\section{Evidence of caspase-3 protein alteration after ischemia}

Normally, caspase- 3 protease is synthesized in cells as an inactive precursor $(32 \mathrm{kDa})$. After activation, it is cleaved at the $\mathrm{C}$ termi- nal of two specific aspartic acid residues to form two mature subunits, p17 (17 kDa) and p12 (12 kDa) (Nicholson et al., 1995). Using the antibody against the deduced C-terminal sequence of the larger subunit (see Materials and Methods), we found that Western blots recognized both precursor and p17 but not p12 in brain protein extracts (Fig. 3). Normal nonischemic hippocampus and caudate-putamen showed fairly high levels of the caspase-3 precursor but none or very low levels of the p17 subunit. After ischemia, caspase-3 protein was increased in these regions (Fig. 3). In the hippocampus, the p17 subunit began to increase at $4 \mathrm{hr}$ and markedly increased at $24-72 \mathrm{hr}$ after ischemia. The levels of the precursor protein were also increased in this region at 8-72 hr. In the caudate-putamen, the p17 form was significantly increased and peaked at $8-24 \mathrm{hr}$ after ischemia. The levels of the precursor protein, however, were unchanged after ischemia. The specificity of the caspase-3 immunoreactivity was confirmed in duplicate Western blots by preabsorbing the primary antibody with the specific caspase- 3 peptide $(5 \mu \mathrm{g} / \mathrm{ml})$, which abolished the signals (data not shown). Neither the p17 nor the precursor protein was increased in the cortex 4-72 hr after ischemia (Fig. 3).

The cellular distribution of caspase- 3 immunoreactivity in the brain was examined using immunohistochemistry. In contrast to the Western blot findings in normal nonischemic brains, neurons throughout most forebrain regions, including hippocampus, caudate-putamen, thalamus, and cortex, contained very weak or no caspase-3 immunoreactivity. As shown in Figure 4, basal caspase-3 immunoreactivity was exclusively present in the cell cytoplasm. Only very few scattered, shrunken neurons in the cortex and thalamus were highly caspase-3-immunoreactive and exhibited nuclear caspase- 3 immunoreactivity. These results are consistent with recent observations in adult human brain tissues (Krajewska et al., 1997). Immunostaining in ischemic brains showed increased caspase- 3 reactivity in several regions affected by global ischemia (Fig. $4 a-f$ ). In the hippocampal CA1 (but not CA3) neurons, increased caspase- 3 immunoreactivity began to be detectable at $8 \mathrm{hr}$ after ischemia and became maximal at $72 \mathrm{hr}$. At the earlier time points $(8-24 \mathrm{hr})$, most cells in the CA1 sector had normal morphology, and the immunoreactivity was predominantly present in the cytosol. At $72 \mathrm{hr}$ after ischemia, however, the majority of cells in this region $(>90 \%)$ showed pyknotic changes (shrinkage of the cell body and condensation of the nucleus). The increased immunoreactivity was distributed throughout the entire cell, including the nucleus. The hippocampal dentate granule cell layers also showed mildly increased caspase-3 immunoreactivity at $8 \mathrm{hr}$ but not at 24 or $72 \mathrm{hr}$ after ischemia. In the dentate, immunoreactivity was diffusely distributed through the cell bodies. The other brain region showing a marked increase in cellular caspase-3 immunoreactivity after ischemia was the caudate-putamen. Many neurons in this region showed increased caspase-3 immunoreactivity 24-72 hr after ischemia. Many cells had pyknotic changes and showed increased immunoreactivity in the nucleus.

\footnotetext{
hippocampal CA1 sector, CA3 sector, and dentate gyrus at 4, 8, 24, 72, and $96 \mathrm{hr}$ after ischemia versus sham controls $(n=3$ per group), determined by optical density measurement on autoradiograms. Data are reported as mean \pm SEM and represent fold changes in ischemic brains versus sham controls; ${ }^{*} p<0.01$, and ** $p<0.001$ versus sham controls (ANOVA and post hoc Fisher's PLSD tests). C, Representative emulsion-coated sections counterstained with cresyl violet from a brain $72 \mathrm{hr}$ after ischemia $(a, c, e)$ and a sham control brain $(b, d, f)$. Caspase-3 mRNA is predominantly increased in the CA1 sector of ischemic hippocampus $(a$; arrows) compared with the control brain $(b)$. Under a high-power field $(400 \times)$, increased amounts of silver grains localize to CA1 pyramidal neurons $(c)$ and to scattered neurons in the caudate-putamen $(e ;$ arrows $)$ compared with the controls $d$ and $f$, respectively. The open squares in $a$ and $b$ mark the regions from which the high-power views in $c$ and $d$ are taken, respectively. $g$, Sense control in caudate-putamen from the same ischemic brain. Scale bar, $30 \mu \mathrm{m}$.
} 

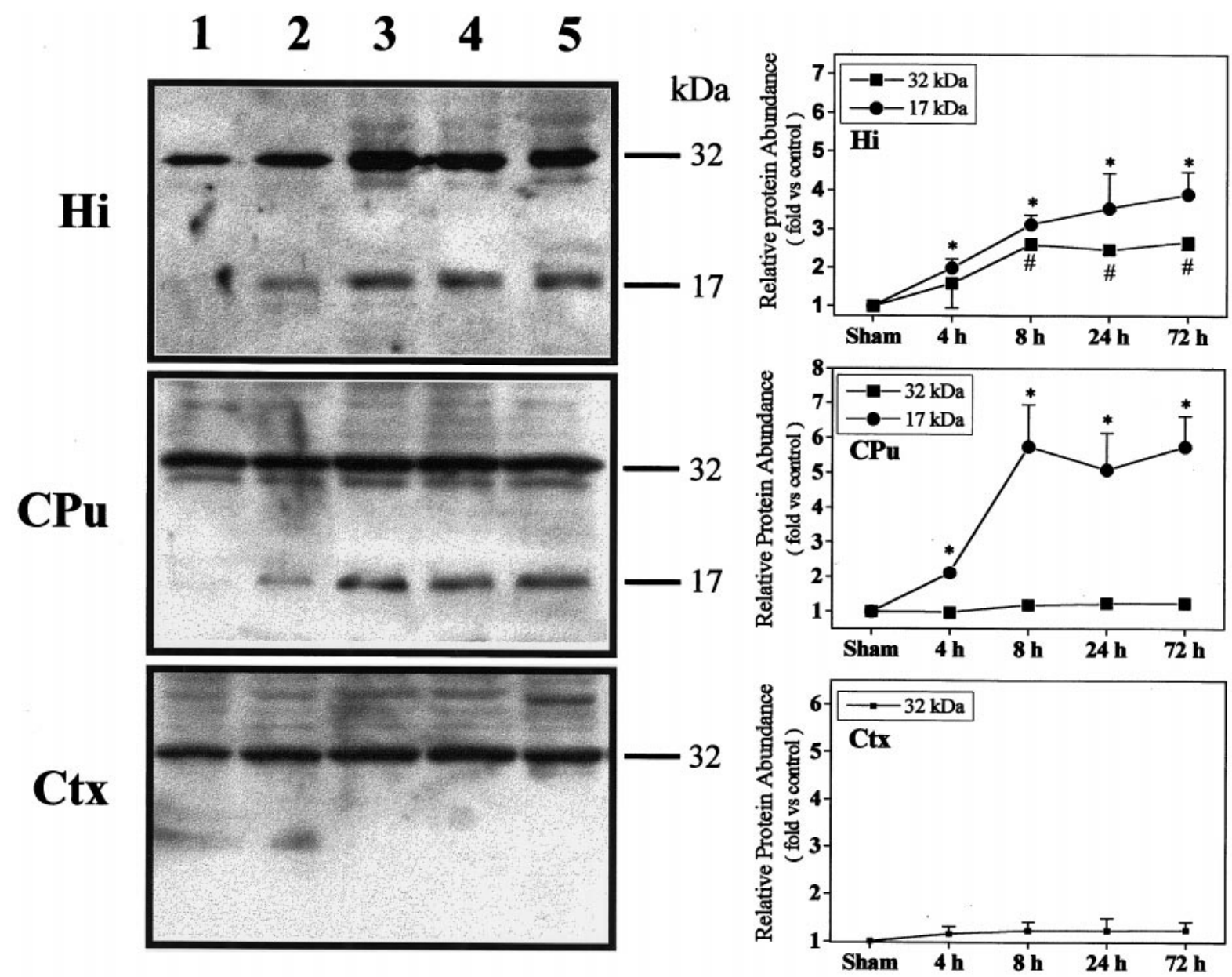

Figure 3. Western blot analysis of caspase-3 protein in the hippocampus $(\mathrm{Hi})$, caudate-putamen $(\mathrm{CP} u)$, and cortex $(\mathrm{Ctx})$ from brains after sham operation (lane 1) or $4 \mathrm{hr}$ (lane 2), $8 \mathrm{hr}$ (lane 3), $24 \mathrm{hr}$ (lane 4), or $72 \mathrm{hr}$ (lane 5) after ischemia. Immunoreactivity of both caspase-3 precursor protein $(32 \mathrm{kDa})$ and its larger cleavage form $(17 \mathrm{kDa})$ is increased in the hippocampus after ischemia. Immunoreactivity of the $17 \mathrm{kDa}$ cleavage form is also increased in the caudate-putamen but not in the cortex. Graphs, Semiquantitative changes of caspase-3 protein after ischemia, determined by optical density $(\mathrm{OD})$ measurements on Western blot autoradiograms $(\mathrm{OD} \times$ area $)$. Data are mean \pm SEM $(n=4$ per time point $)$ and represent fold changes in ischemic brains versus sham controls; ${ }^{*}{ }^{*} p<0.05$ versus sham controls (ANOVA and post hoc Fisher's PLSD tests).

To address the potential role of caspase- 3 protein induction in ischemic cell death, we performed double staining for caspase-3 protein and DNA fragmentation in brain sections obtained 24 and $72 \mathrm{hr}$ after ischemia, when substantial cell death began to occur in the caudate-putamen and hippocampus, respectively. In the hippocampal CA1 sector, the majority of DNA-fragmented (TUNEL-positive) neurons showed increased nuclear caspase-3 immunoreactivity at $72 \mathrm{hr}$ (Fig. $4 e-h$ ) and vice versa. In the caudate-putamen, especially the dorsolateral portion, many pyknotic cells showed colocalization of increased nuclear caspase- 3 immunoreactivity and DNA fragmentation at 24 and $72 \mathrm{hr}$ after ischemia (Fig. 4f,h). Colocalization of increased nuclear caspase-3 immunoreactivity and DNA fragmentation was also detected in a few scattered neurons in layers III and V of the cortex. In sham-operated control brains $(n=4)$, zero to three cells per section showed DNA fragmentation. No colocalization of DNA fragmentation and caspase-3 immunoreactivity was found in these brains.

TUNEL staining was also performed in adjacent brain sections using the horseradish-streptavidin-peroxidase method (Chen et al., 1997b), and positive versus negative cells in the hippocampus and caudate-putamen $(\mathrm{CPu})$ were quantified. Twenty-four hours after ischemia, $31.5 \pm 8.9 \%$ (mean \pm SEM; $n=4)$ of the total number of cells in the $\mathrm{CPu}$ at the midcaudate level showed TUNEL-positive staining, whereas $<0.5 \%$ of the CA1 neurons stained positively. At $72 \mathrm{hr}$ after ischemia, however, $86.5 \pm 4.3 \%$ of the neurons in the CA1 and $52.7 \pm 11.4 \%$ of the cells in the $\mathrm{CPu}$ were TUNEL positive (mean $\pm \mathrm{SEM} ; n=4$ at each coronal level). In both regions, the majority of TUNEL-positive cells exhibited shrinkage of cytoplasm and nucleus and condensation of chromatin. Many cells in the $\mathrm{CPu}$ also showed formation of two or more dense masses around the nucleus suggestive of apoptotic bodies, as described by others ( $\mathrm{Li}$ et al., 1995; Charriaut-Marlangue et al., 1996). Meanwhile, only a small portion of TUNEL-positive cells in the CA1 sector $(<10 \%$ of the total number of positive cells), mainly in CA1a, exhibited significant morphological changes indicative of necrosis, such as diffused cytosol staining or loss of cellular structures (CharriautMarlangue et al., 1996). Thus, many but not all ischemic neurons in this model show morphological features of apoptotic cell death. 

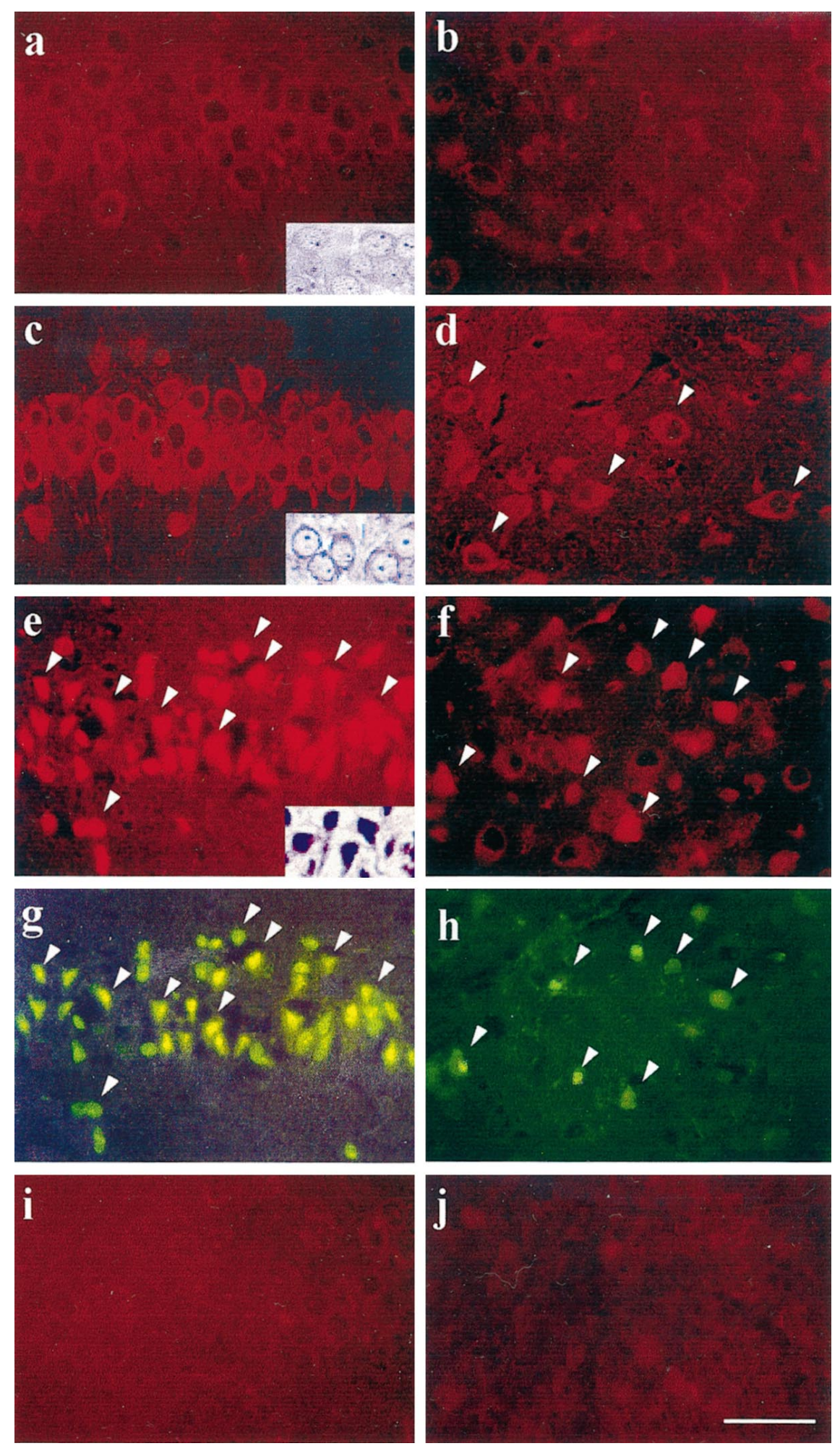

Figure 4. Immunofluorescent images of caspase-3 protein $(a-f, i, j)$ and TUNEL labeling $(g, h)$ in the hippocampal CA1 sector (left) and caudate-putamen (right) after ischemia. Compared with that in the control brain $(a, b)$, caspase- 3 immunofuorescence is increased in the cytoplasm of CA1 pyramidal neurons (c) and in scattered neurons in the caudate-putamen (d; arrowheads) at $24 \mathrm{hr}$ after ischemia. Caspase-3 immunofluorescence is increased further in neurons in these regions with both cytosolic and nuclear localization at $72 \mathrm{hr}$ after ischemia (e,f; arrowheads mark representative positive cells). Double-label (TUNEL) in the same sections shows a colocalization of DNA fragmentation $(g, h$; arrowheads mark representative positive cells) and increased caspase- 3 immunofluorescence in most CA1 neurons ( $e$ vs $g$ ) and in many caudate neurons $(f$ vs $h)$ at $72 \mathrm{hr}$ after ischemia. Note that TUNEL-positive neurons show a condensed and shrunken nucleus. Consecutive sections of $c$ and $d$ incubated with the primary antibody preabsorbed with the synthetic caspase-3 peptide show background fluorescence only $(i, j)$. Insets in $a, c$, and $e$ show representative cresyl violet staining in the CA1 sector. In keeping with the delayed manner of cell death in this model, CA1 neurons show normal morphology in control brain $(a)$ and in the brain $24 \mathrm{hr}$ after ischemia (c) but show pyknotic changes in the brain $72 \mathrm{hr}$ after ischemia (e). Scale bar, $50 \mu \mathrm{m}$.
These observations are consistent with previous findings in similar animal models (Kihara et al., 1994; Nitatori et al., 1995; Chen et al., 1996).

\section{Alteration of caspase-3- and ICE-like protease activities after ischemia}

To assay for protease activity, we incubated cell lysates with Ac-DEVD- $p$ NA as a substrate for caspase-3 and Ac-YVAD- $p$ NA as a substrate for ICE and monitored release of $p$-nitroanilide.
Lysates from normal nonischemic brains showed low levels of both ICE- and caspase-3-like peptide cleavage activities, which were blocked, but not completely, by saturated concentrations of the ICE inhibitor YVAD-CHO $(5 \mu \mathrm{M})$ and the caspase-3 inhibitor DEVD-CHO (5 $\mu \mathrm{M})$. The levels measured after inhibitor treatment were considered nonspecific background signals present in the lysates and were subsequently subtracted from all readings, as suggested previously (Enari et al., 1996). Lysates 

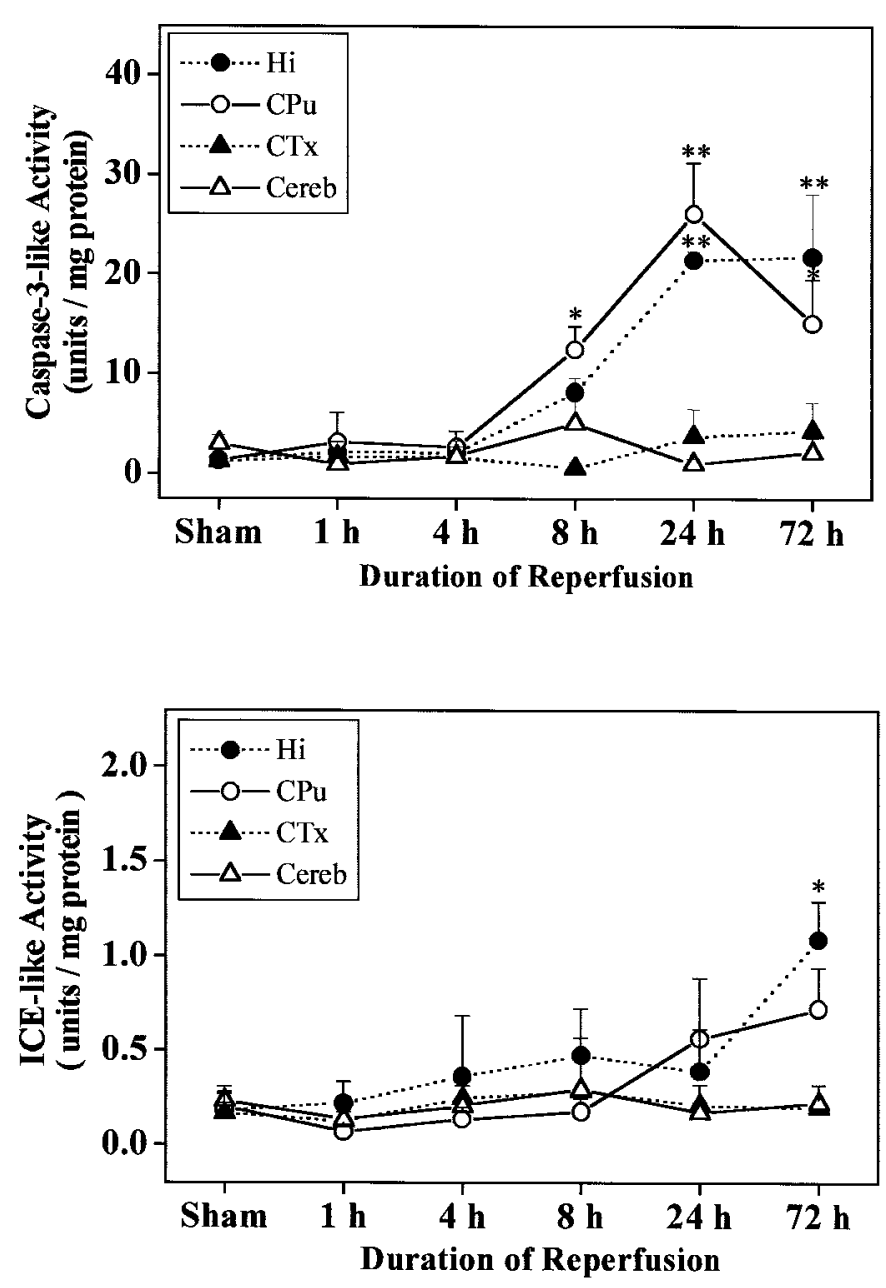

Figure 5. The caspase-3-like (top) and ICE-like protease activity (bottom $)$ in cell extracts from the hippocampus $(\mathrm{Hi})$, caudate-putamen $(\mathrm{CPu})$, cortex $(C T x)$, and cerebellum (Cereb) after sham operation or 1, 4, 8, 24, or $72 \mathrm{hr}$ after ischemia. The protease activities are measured by determining the ability of cell extracts to cleave the colorimetric substrates Ac-DEVD- $p$ NA (for caspase-3-like activity) and Ac-YVAD-pNA (for ICE-like activity). One unit of protease activity corresponds to the caspase-like activity that cleaves 1 pmol of $p$ NA per minute at $37^{\circ} \mathrm{C}$ at saturating substrate concentrations. Data are presented as mean \pm SEM $\left(n=4-5\right.$ per time point); ${ }^{*} p<0.05$, and ${ }^{* *} p<0.01$ versus sham controls (ANOVA and post hoc Fisher's PLSD tests).

from the ischemic hippocampus and caudate-putamen exhibited an increase in Ac-DEVD- $p$ NA peptide cleavage activity that was detectable at $8 \mathrm{hr}$ and maximal at 24-72 hr after ischemia (Fig. 5, top). The increased caspase-3-like protease activity was completely inhibited by DEVD-CHO but was not affected by YVAD$\mathrm{CHO}$ (data not shown). Moreover, lysates from ischemic hippocampus also exhibited a mild increase in Ac-YVAD- $p$ NA cleavage activity that was detectable only at $72 \mathrm{hr}$ after ischemia (Fig. 5, bottom). By contrast, there was no significant induction of ICE-like activity in the caudate-putamen at any time point tested. Neither caspase-3-like nor ICE-like protease activity was significantly increased in the cortical or cerebellum lysates at any time point after ischemia.

The finding that ischemia markedly induces Ac-DEVD-pNA cleaving activity in both the hippocampus and caudate-putamen prompted an analysis of poly(ADP-ribose) polymerase (PARP) cleavage and other potential caspase-3 cleavage substrates. West- ern blots using the C-2-10 monoclonal antibody detected increased cleavage of intact PARP $(116 \mathrm{kDa})$ to the $85 \mathrm{kDa}$ apoptosis-related cleavage fragment in ischemic brains (Fig. 6). The $85 \mathrm{kDa}$ fragment was present at negligible levels in normal nonischemic brains. However, these levels were significantly increased after ischemia (24-72 hr after ischemia in the caudateputamen and $72 \mathrm{hr}$ after ischemia in the hippocampus). Duplicate Western blots performed using the primary antibody preabsorbed with the purified bovine PARP protein $(10 \mu \mathrm{g} / \mathrm{ml})$ showed a complete loss of signal at both 116 and $85 \mathrm{kDa}$ (Fig. $6 a$ ), confirming the specificity of the immunoreactivity recognized by the PARP antibody. Moreover, PARP cleavage was not detected in the cortex 4-72 hr after ischemia (data not shown).

Considering that induced caspase- 3 protease activity after ischemia may result in the cleavage of other substrates in the ischemic brain as well, we also analyzed two other proteins, the DNAdependent protein kinase and actin. Both proteins have been found to be cleaved under certain apoptotic conditions in several cell systems (Casciola-Rosen et al., 1995; Mashima et al., 1995; Song et al., 1996; McConnell et al., 1997), however, no specific cleavage products from either of the two proteins were detected in cell extracts from the hippocampus or caudate-putamen with or without ischemic insults (data not shown).

\section{Effects of inhibition of caspase-3-like protease activity after ischemia}

To investigate the cell death regulatory role of caspase- 3 in ischemic brain injury further, we infused Z-DEVD-FMK, an inhibitor of caspase-3, into the ventricles beginning $30 \mathrm{~min}$ before the induction of ischemia. DMSO was used as a vehicle. The doses of Z-DEVD-FMK used in the histological outcome studies were predetermined by a set of dose-response experiments, in which the ability of Z-DEVD-FMK to inhibit caspase-3-like protease activity in ischemic brains was examined.

Animals that received either no infusion, vehicle infusion, or peptide infusion all survived the experiments. At the highest dose $(1.5 \mu \mathrm{g} \times 3)$, Z-DEVD-FMK did not cause any notable behavioral abnormalities in the animals or microscopic evidence of cell death in normal nonischemic brains, determined by cresyl violet staining $72 \mathrm{hr}$ after infusion $(n=4)$. Brain and rectal temperatures were not altered by infusion of the peptide before, during, or after ischemia. The EEG reached isoelectricity within $10 \mathrm{sec}$ of the induction of ischemia in all animals. In the brains of animals subjected to $15 \mathrm{~min}$ of ischemia followed by $48 \mathrm{hr}$ of reperfusion, Z-DEVD-FMK infusion decreased Ac-DEVD- $p$ NA peptide cleavage activity in the hippocampus in a dose-dependent manner (Fig. 7aE).

In histological outcome studies, Z-DEVD-FMK partially but significantly decreased neuronal death in the hippocampal CA1 sector at $72 \mathrm{hr}$ after ischemia (Fig. $7 a A, a B$ ). The protective effect of Z-DEVD-FMK was detectable at higher doses, and the effect was more apparent in the hippocampus on the side ipsilateral rather than contralateral to the infusion. To test the efficacy of Z-DEVD-FMK administrated after ischemia, we infused the peptide into the ventricles beginning $2 \mathrm{hr}$ after ischemia and followed with a second infusion $22 \mathrm{hr}$ later (total dose, $4.5 \mu \mathrm{g}$ ). Post-treatment with Z-DEVD-FMK increased CA1 neuron survival in the hippocampus bilaterally $72 \mathrm{hr}$ after ischemia, with an efficacy similar to that of pretreatment. To determine whether Z-DEVD-FMK promotes CA1 neuron survival after a longer period of reperfusion, we gave two additional groups of animals either vehicle or peptide pretreatment $(1.5 \mu \mathrm{g} \times 3)$, and brain 

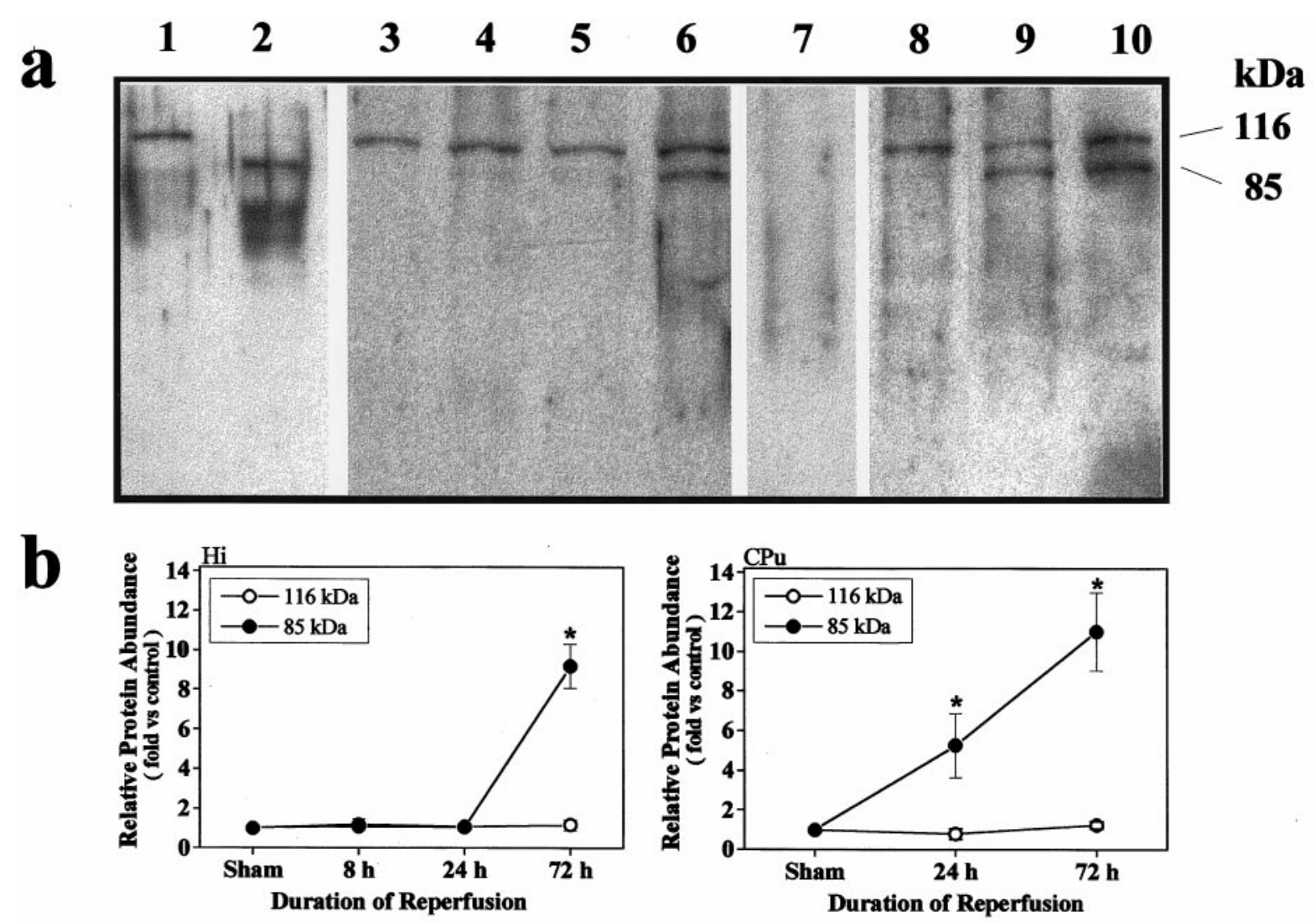

Figure 6. Western blot analysis of PARP in the hippocampus and caudate-putamen after ischemia. a, Lanes 1-2, Positive controls for intact PARP (116 $\mathrm{kDa})$ and cleaved PARP ( $85 \mathrm{kDa})$ using cell extracts from uninduced human HL60 leukemia cells and HL60 induced to undergo apoptosis, respectively. Lanes 3-6, Cell extracts from the hippocampus after sham operation (lane 3) or $8 \mathrm{hr}$ (lane 4), $24 \mathrm{hr}$ (lane 5), or $72 \mathrm{hr}$ (lane 6 ) after ischemia. Note that the $85 \mathrm{kDa}$ form of PARP is increased at $72 \mathrm{hr}$. Lane 7, The same cell extract used in lane 6 incubated with the primary antibody preabsorbed with purified bovine PARP protein $(10 \mu \mathrm{g} / \mathrm{ml})$. Lanes $8-10$, Cell extracts from the caudate-putamen after sham operation (lane 8) or $24 \mathrm{hr}$ (lane 9 ) or $72 \mathrm{hr}$ (lane 10) after ischemia. Note that the $85 \mathrm{kDa}$ form is increased in both ischemic samples. $b$, Semiquantitative analysis of relative PARP changes in the hippocampus $(\mathrm{Hi})$ and caudate-putamen $(\mathrm{CP} u)$ after ischemia. Data are mean \pm SEM $(n=3$ per time point $) ;{ }^{*} p<0.05$ versus sham controls $(\mathrm{ANOVA}$ and post hoc Fisher's PLSD tests).

sections were obtained for analysis $7 \mathrm{~d}$ after ischemia. Z-DEVDFMK significantly increased CA1 neuron survival, although to a lesser extent compared with the outcome at $3 \mathrm{~d}$ (Fig. 8). In all treatment paradigms tested (before or after treatment or a longer period of reperfusion), Z-DEVD-FMK significantly decreased the number of CA1 neurons that exhibited DNA fragmentation after ischemia (Fig. 7aC, $a D$ ). Representative micrographs showing histological outcome and DNA fragmentation after ischemia with or without peptide infusion are presented in Figure 8.

Because Z-DEVD-FMK, like all other commercially available caspase inhibitors, may act on multiple caspases instead of inhibiting caspase-3 only, another caspase inhibitor, Z-YVAD-FMK, which has a preferential action on ICE, was also tested in the present study. At both doses equivalent to the effective doses for Z-DEVD-FMK $(0.5 \mu \mathrm{g} \times 3$ and $1.5 \mu \mathrm{g} \times 3)$, Z-YVAD-FMK failed to show significant protection in CA1 neurons $3 \mathrm{~d}$ after ischemia (Fig. $7 b$ ).

\section{DISCUSSION}

A number of gene products may be modulators of neuronal apoptosis resulting from cerebral ischemia and related brain insults (for review, see Bredesen, 1995; Koistinaho and Hokfelt, 1997). In the present study, we demonstrate that caspase-3, a key member of the ICE protease family, was induced in neurons after transient global ischemia. Caspase-3 mRNA and protein were increased in the hippocampus and caudate-putamen, which are selectively vulnerable to ischemic injury. The caspase-3 precursor was proteolytically activated, and caspase-3-like protease activity was increased in these vulnerable brain regions before and coincidental with cell death. The specific caspase- 3 protease substrate PARP was cleaved in these regions when substantial amounts of cell death occurred. Finally, inhibition of caspase-3-like protease activity using a tetrapeptide inhibitor significantly decreased neuronal death and DNA fragmentation in the hippocampal CA1 sector up to $7 \mathrm{~d}$ after ischemia. These results strongly support the hypothesis that the caspase- 3 protease is an inducible cell death effector in the brain after ischemic injury.

Consistent with previous observations, caspase- 3 mRNA and protein are present at low levels in the adult brain (Krajewska et al., 1997; Ni et al., 1997). After transient global ischemia, expression of both caspase-3 mRNA and protein was markedly increased in the brain. Although caspase-3 gene expression was transiently and modestly increased in less vulnerable cells such as dentate granule cells $8 \mathrm{hr}$ after ischemia, a greater and prolonged increase, lasting up to $72 \mathrm{hr}$ after ischemia, was found in selectively vulnerable CA1 and striatal neurons destined to die. These data confirm recent findings regarding cpp32 mRNA expression in a rat model of cardiac arrest (Gillardon et al., 1997). This pattern of expression is also similar to that of Bax, another 
a
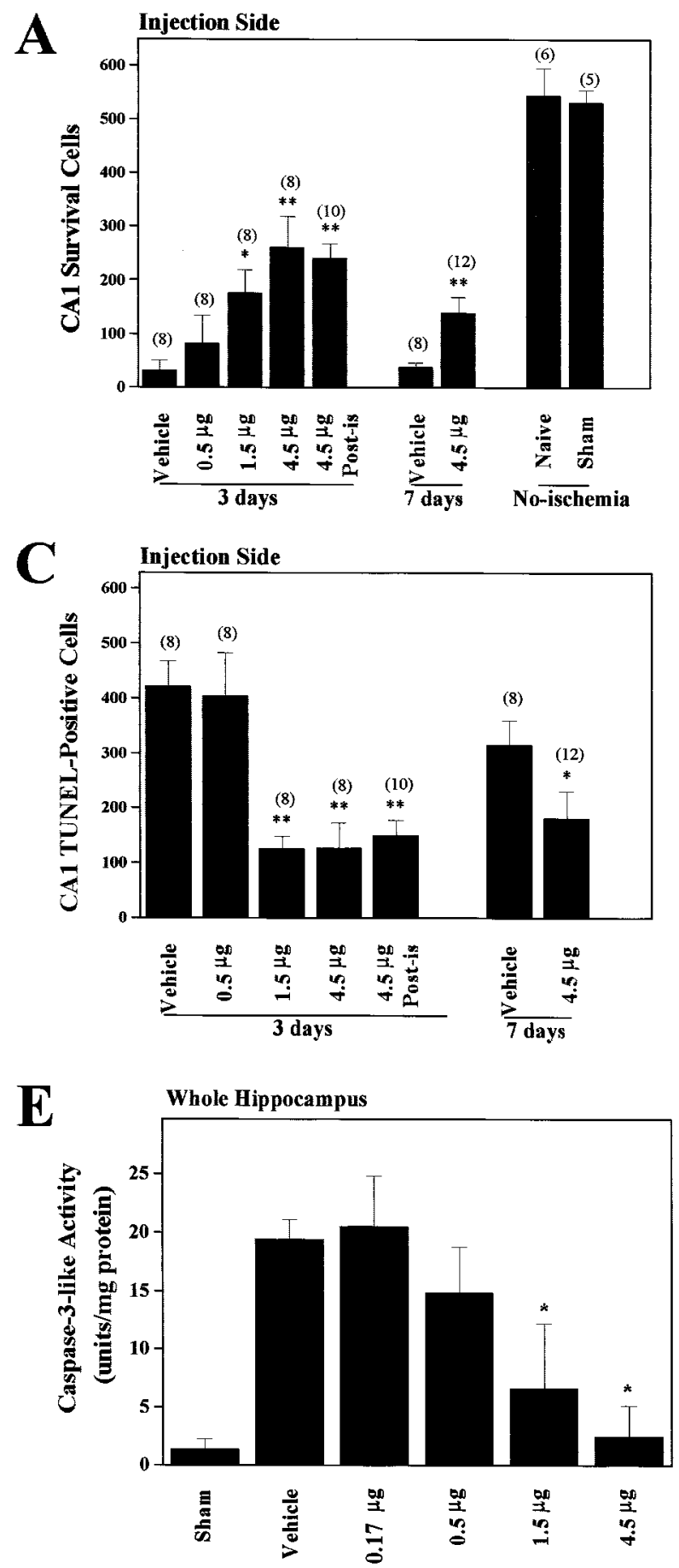

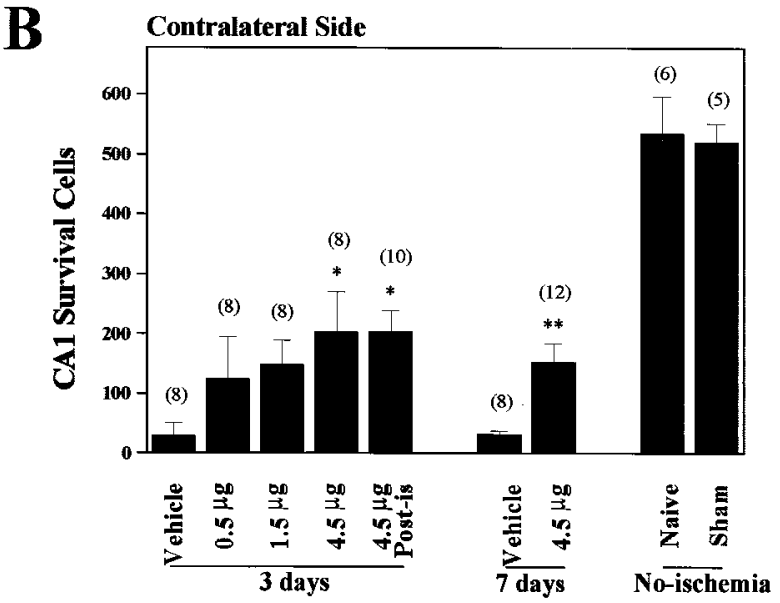

D

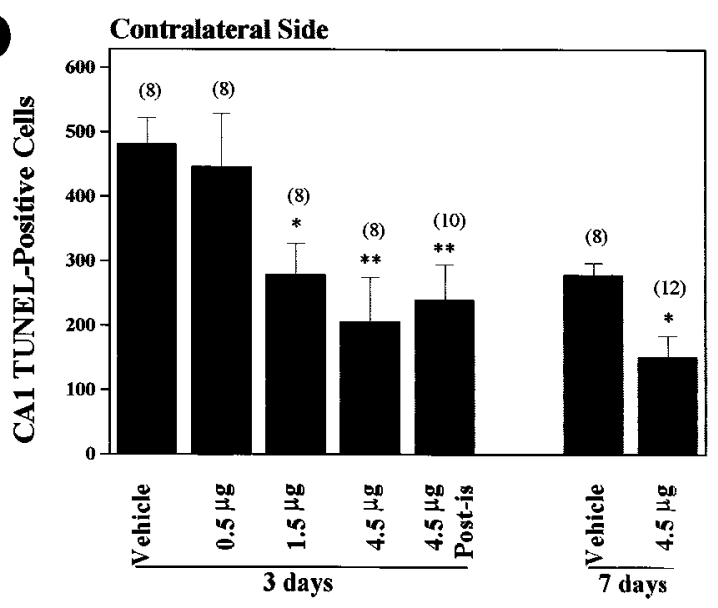

Figure 7. a, Quantitative analysis of effect of in vivo caspase-3 inhibitor treatment on hippocampal CA1 neuron survival $(A, B)$, DNA fragmentation $(C$, $D$ ), and caspase-3-like activity after ischemia $(E) . A, B$, Dose-dependent increase in CA1 neuron survival after ischemia by the caspase-3 inhibitor Z-DEVD-FMK, either injected before the induction of ischemia (vehicle or total dose of $0.5,1.5$, or $4.5 \mu \mathrm{g}$ ) or after ischemia (post-is with total dose of $4.5 \mu \mathrm{g}$ ). Cresyl violet staining and cell counting were performed either 3 or $7 \mathrm{~d}$ after ischemia. $C, D$, Dose-dependent decrease in the amount of cells with DNA fragmentation (TUNEL positive) in CA1 after ischemia by inhibiting caspase-3-like protease activity. No DNA fragmentation is present in CA1 in naive or sham-operated brains (data not shown). Sections through the same level of the dorsal hippocampus (bregma, $-4.0 \mathrm{~mm}$ ) are used for the analysis. Cell counting includes the entire CA1 sector at this level. E, Dose-dependent inhibition of caspase-3-like activity in the hippocampus by Z-DEVD-FMK. Vehicle $(n=4)$ or the peptide (total dose of $0.17,0.5,1.5$, or $4.5 \mu \mathrm{g})$ was inf used beginning 30 min before ischemia $(n=5$ each dose). Caspase-3-like activity was measured in hippocampal cell extracts $48 \mathrm{hr}$ after ischemia. All data are reported as mean $\pm \mathrm{SEM}$; * $p<0.01$, and ${ }^{* *} p<$ 0.001 (ANOVA and post hoc Fisher's PLSD tests). $b$, Quantitative analysis of effect of in vivo ICE inhibitor Z-YVAD-FMK treatment on hippocampal CA1 neuron survival $(A)$ and DNA fragmentation $(B) 3 \mathrm{~d}$ after ischemia. No significant protection by Z-YVAD-FMK was detected. Injection Side, The hemisphere receiving inhibitor infusion; contralateral side, the hemisphere receiving no infusion. The number in parentheses indicates the number of animals in that experimental group. 
b

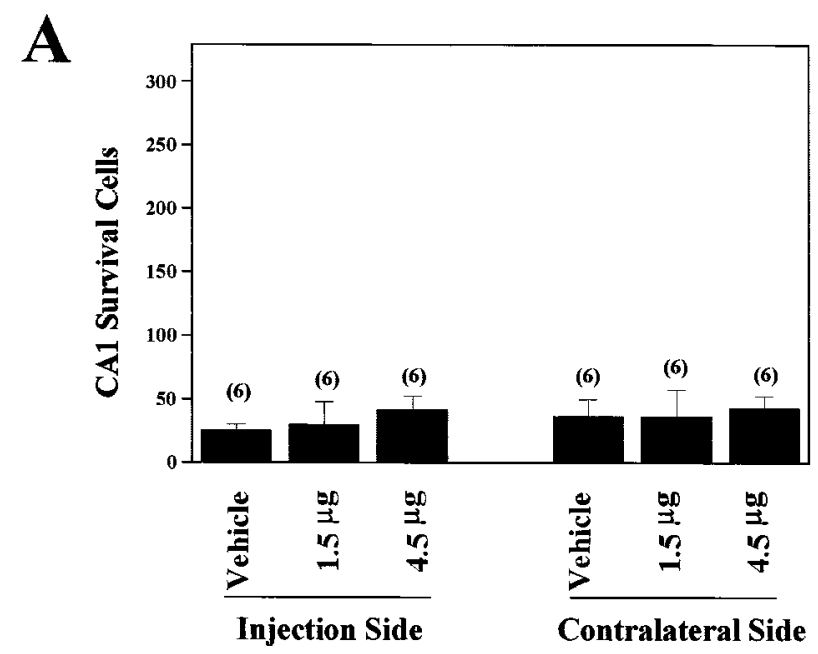

B

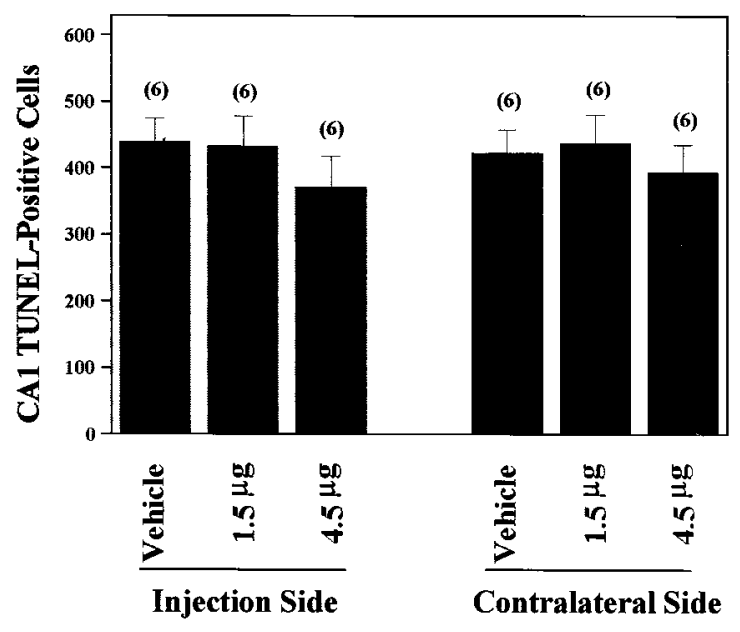

Figure $7 b$

proapoptotic gene studied in similar animal models of global ischemia (Krajewski et al., 1995; Chen et al., 1996). With rare exceptions, cells containing fragmented DNA also showed highly increased caspase-3 immunoreactivity (Fig. 4). Such colocalization of DNA fragmentation and elevated caspase-3 immunoreactivity was detected in a majority of neurons in the CA1 sector and many neurons in the $\mathrm{CPu}$ at $72 \mathrm{hr}$ after ischemia. These results are consistent with a potential role for caspase-3 as a neuronal death effector in ischemic neurons.

As seen with other ICE family proteases, post-translational activation of caspase- 3 requires proteolytic cleavage of the precursor protein, in this case into two subunits (p17 and p12), the larger of which contains the catalytic site (Fernandes-Alnemri et al., 1994). In the present study, an increase in p17 immunoreactivity began to be detectable in the hippocampus and $\mathrm{CPu} 4 \mathrm{hr}$ after ischemia and peaked at 24-72 hr (Fig. 3). Nearly coincident with the time course of caspase-3 proteolytic cleavage after ischemia, caspase-3-like protease activity was selectively increased in the same brain regions, suggesting that proteolytic cleavage of caspase-3 may directly contribute to the increase in caspase-3 protease activity after ischemia. The increased caspase- 3 pro- tease activity was detected in brain regions in which cell death was eventually substantial (the hippocampus and $\mathrm{CPu}$ ) but not in regions either less vulnerable to ischemia (the cortex) or unaffected by ischemia in this model (the cerebellum). Thus, we suggest that cell death after global ischemia is associated with post-translational activation as well as gene induction of caspase-3, with the proteolytic cleavage event slightly preceding gene upregulation. The mechanism by which the caspase- 3 gene is induced and the caspase- 3 precursor is cleaved after ischemia is unclear. Ischemia-induced glutamate release could be a trigger for caspase-3 gene induction (Du et al., 1997). A number of studies suggests that caspase-3 can be either autoactivated or activated by ICE or nedd2, Mch2a/CAP, Mch4, and Mch5 (Kumar et al., 1994; Tewari et al., 1995; Fernandes-Alnemri et al., 1996; Liu et al., 1996). It is possible that ischemia activates ICE or other upstream proteases, which lead to the activation of caspase-3. Subsequently, active caspase-3 and overexpression of caspase-3 could contribute to autoactivation of this enzyme. Accordingly, we speculated that ICE might be induced or activated during earlier reperfusion periods after ischemia. However, we could not detect increased ICE mRNA expression in the brain 0.5-72 hr after ischemia (data not shown). Moreover, ICE-like protease activity was only modestly increased in the hippocampus and only after $72 \mathrm{hr}$ of reperfusion and was not increased in the $\mathrm{CPu}$ (Fig. 5). The ICE inhibitor Z-YVAD-FMK failed to provide significant protection in CA1 (Fig. $7 b$ ). These data do not support ICE as the main trigger responsible for the activation of caspase-3 and subsequent neuronal death after global ischemia.

The regional and temporal profile of caspase- 3 induction after ischemia supports a role of this enzyme in ischemic neuronal death; however, a causal relationship between these two events cannot be deduced from the expression data alone. Consequently, we have studied the effect of inhibiting caspase- 3 activity on cell survival after ischemia. The tetrapeptide inhibitor Z-DEVDFMK significantly reduced caspase-3-like protease activity in ischemic hippocampus and significantly decreased CA1 cell loss, with a similar efficacy whether given before or after ischemia. The protective effect of Z-DEVD-FMK on CA1 neuron survival is unlikely to be caused by its effects on brain temperature or ischemia induction (as judged by EEG measurement). However, we must interpret these data with great caution. Because the tetrapeptide inhibitor was designed based on the PARP cleavage site (Lazebnik et al., 1994), caspase-3 may not be the sole caspase inhibited by Z-DEVD-FMK. Several caspase-3-related proteases including Mch2a and Mch3a are also capable of cleaving PARP or the $N$-acetyl-Asp-Glu-Val-Asp-(7-amino-4-methylcoumarin) (DEVD-AMC) substrate reminiscent of the PARP cleavage site (Fernandes-Alnemri et al., 1995). Ich-2/Tx and Ich-1/nedd2 can cleave PARP, but this requires very high enzyme-substrate ratios (for review, see Zhivotovsky et al., 1996). Thus, we cannot exclude the possibility that the protective effect achieved by the caspase-3 inhibitor is via the inhibition of other caspase-3-like enzymes. To address this issue, it will be helpful to compare ischemic injury in naive and caspase-3-deficient (knock-out) animals. Nevertheless, the fact that the caspase-3 gene is induced and its enzymatic activity is increased after ischemia provides strong evidence to link ischemic cell death to the activation of caspase-3.

Caspase-3 may mediate ischemic cell death via several mechanisms. Mature caspase-3 can cleave specific cellular proteins. Several proteins have been suggested as potential targets for caspase-3 during apoptosis. The best-characterized death sub- 
A
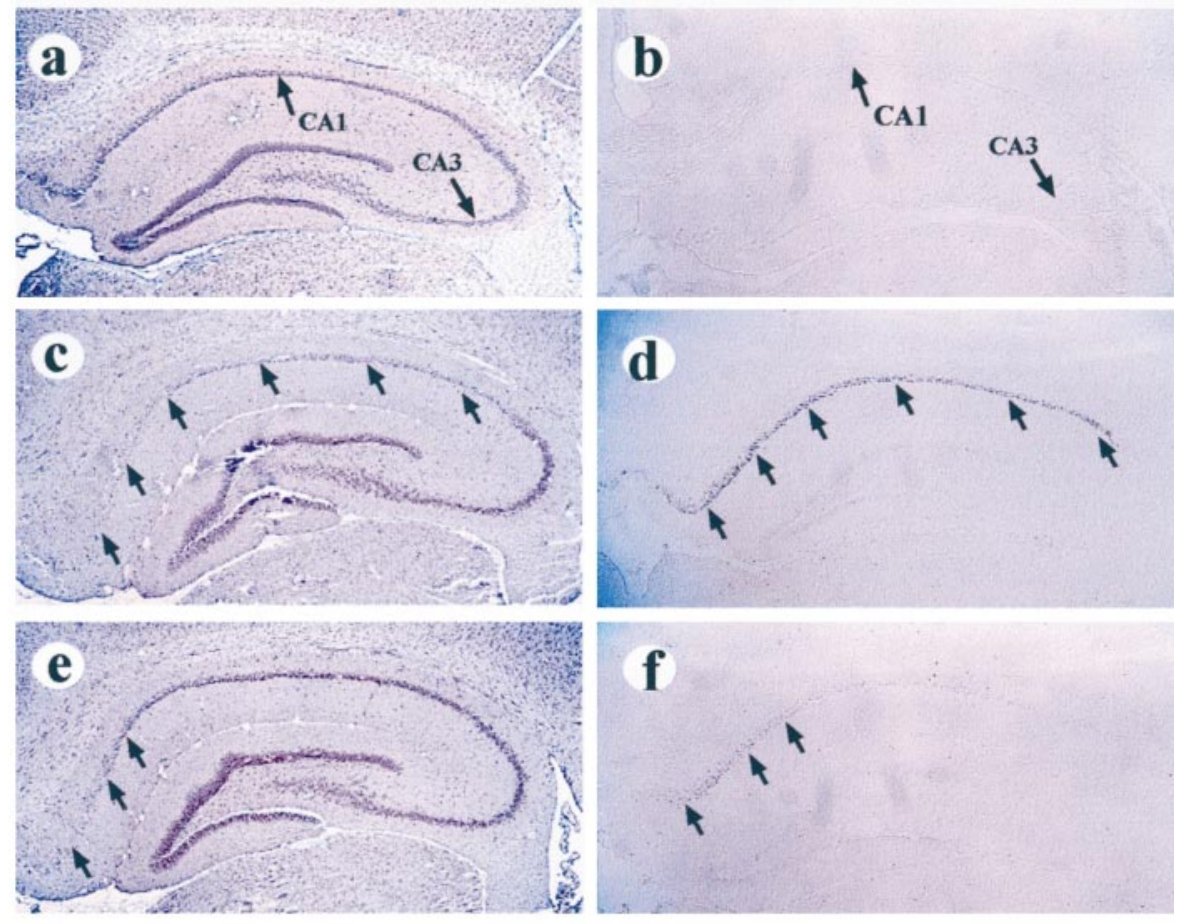

f
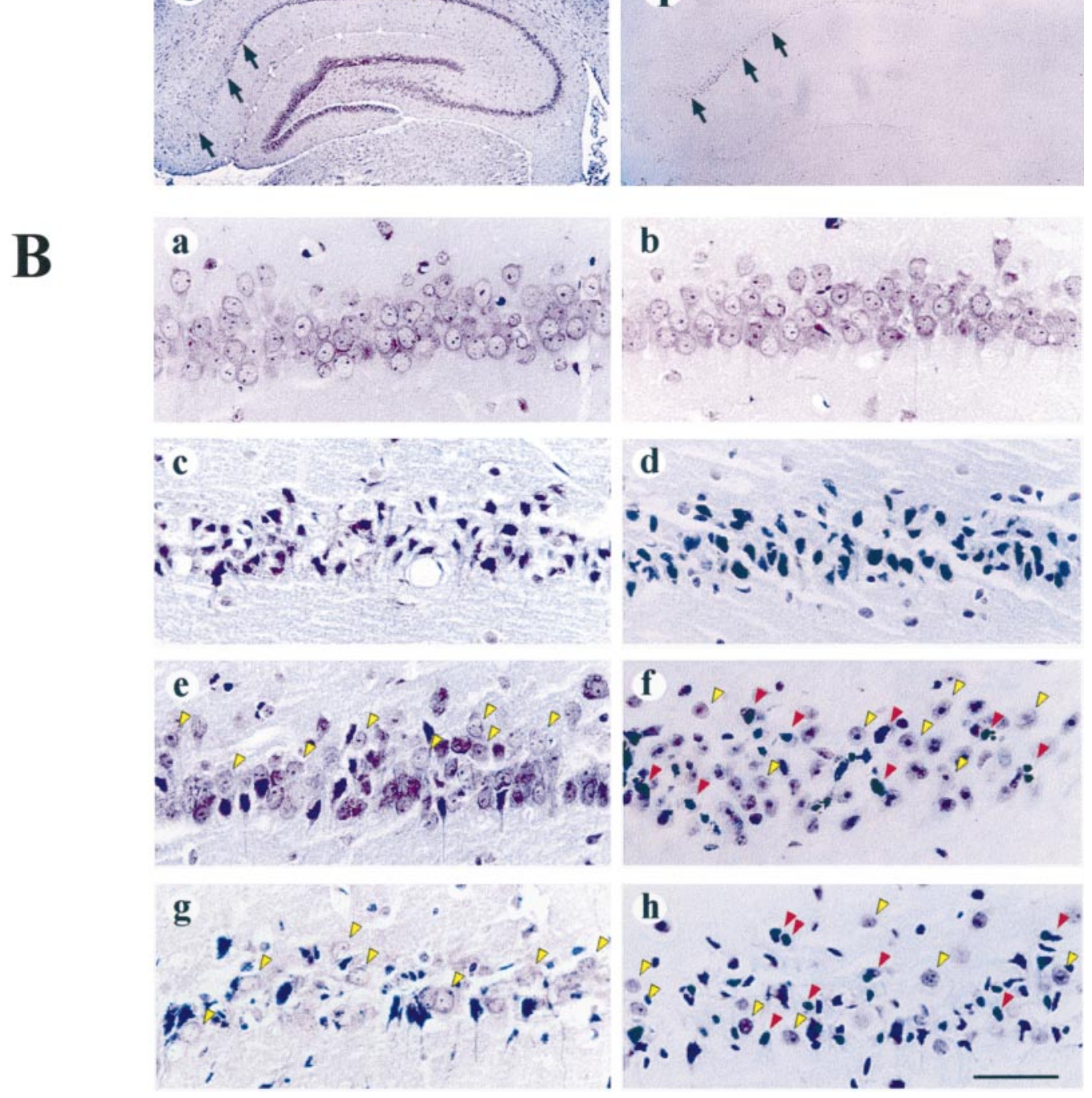

Figure 8. Effect of in vivo caspase-3 inhibition on CA1 neuron survival and DNA fragmentation. $A$, Low-power fields $(40 \times)$ showing representative cresyl violet staining $(a, c, e)$ and TUNEL $(b, d, f)$ in the hippocampus $3 \mathrm{~d}$ after sham operation $(a, b)$, after ischemia plus vehicle inf usion $(c, d)$, or after ischemia plus caspase-3 inhibitor infusion (total dose, $4.5 \mu \mathrm{g} ; e, f$ ). Arrows in $c$ and $e$ mark cell death in the CA1 sector. Arrows in $d$ and $f$ mark DNA-fragmented (TUNEL-positive) cells in the CA1 sector. $B$, High-power fields $(400 \times)$ showing representative cresyl violet staining $(a, c, e, g)$ and TUNEL counterstained with cresyl violet $(b, d, f, h)$ in the CA1 sector. Three days after sham operation $(a, b)$, no cell death or DNA fragmentation is present in CA1; $3 \mathrm{~d}$ after ischemia plus vehicle infusion $(c, d)$, the majority of CA1 neurons show pyknotic changes $(c)$ and TUNEL labeling $(d) ; 3 \mathrm{~d}$ after ischemia plus caspase-3 inhibitor infusion $(e, f)$, many neurons show normal morphology ( yellow arrowheads), and decreased amounts of neurons show pyknotic changes $(e)$ or TUNEL labeling (red arrowheads; $f$ ); and $7 \mathrm{~d}$ after ischemia plus inhibitor infusion $(g, h)$, both survival neurons (yellow arrowheads) and TUNEL-positive cells $($ red arrowheads; $h$ ) are present in the CA1. Scale bar, $50 \mu \mathrm{m}$. 
strate is PARP, an enzyme involved in DNA repair and maintenance of genome integrity (Althaus and Richter, 1987; Satoh and Lindahl, 1992). Under many apoptotic conditions, PARP is cleaved by caspase- 3 to generate the characteristic 85 and $24 \mathrm{kDa}$ fragments (Kaufmann et al., 1993; Fernandes-Alnemri et al., 1995; Nicholson et al., 1995). Other proteins thought to be targets for caspase-3 include DNA-dependent protein kinase (DNA-PK) (Casciola-Rosen et al., 1995; Han et al., 1996), protein kinase C (Hugunin et al., 1996), the transcription factors SREBPs (Wang et al., 1996), and actin (Mashima et al., 1997; Song et al., 1997). In the present study, PARP was partially cleaved to its $85 \mathrm{kDa}$ fragment in vulnerable brain regions after ischemia. No degradation of DNA-PK or actin was detected. Thus, PARP may be a specific substrate for caspase-3 during ischemic cell death, although whether degradation of PARP is an event leading to ischemic cell death is unclear. First, as shown in this study, cleavage of PARP is a late event after ischemia. Second, PARP is a nuclear protein, and although caspase- 3 may be present in the nucleus of degenerated neurons (Fig. 4), there is no direct evidence that mature caspase- 3 is relocated to the nucleus from the cytosol before cell death. Third, under certain circumstances such as focal cerebral ischemia and excitotoxicity, gene disruption or pharmacological inhibition of PARP improves neuronal survival (Eliasson et al., 1997; Endres et al., 1997). Accordingly, cleavage of PARP may not be responsible for neuronal death after ischemia. Instead, PARP degradation may reflect the overall cellular destruction in the final stages of the apoptotic cascade. Another potential mechanism via which caspase-3 might effect cell death after ischemia is by activating other caspases such as Mch2a and Mch6 involved in the apoptotic cascade (Srinivasula et al., 1996). Finally, caspase-3 may promote cell death via the activation of caspase-activated deoxyribonuclease (CAD), a key DNAcleavage enzyme responsible for DNA fragmentation during apoptosis. Enari et al. (1998) recently suggest that caspase-3 activates $\mathrm{CAD}$ by cleaving and releasing the CAD inhibitory protein that normally binds CAD. Future work identifying specific cellular substrates for caspase-3 at early stages of cell death would greatly enhance our understanding of the role of this death protease in ischemic brain injury.

In summary, the present study provides evidence that the caspase-3 gene is induced and its protein product is activated in selectively vulnerable brain regions after ischemia. Caspase-3 activation precedes and its regional distribution correlates with delayed cell death. The caspase- 3 inhibitor decreases protease activity in the hippocampus and increases cell survival in this region after ischemia. The results strongly support a cell deatheffector role for caspase-3-protease in ischemic brain injury. Future development of highly specific methods to inhibit caspase-3like protease activity or its consequences may have therapeutic significance in the treatment of stroke and related neurological disorders.

\section{REFERENCES}

Alnemri ES, Livingston DJ, Nicholson DW, Salvesen G, Thronberry NA, Wong WW (1996) Human ICE/CED-3 protease nomenclature. Cell $87: 171$.

Althaus FR, Richter C (1987) ADP-ribosylation of proteins. Enzymology and biological significance. Mol Biol Biochem Biophys 37:1-237.

Bredesen DE (1995) Neural apoptosis. Ann Neurol 38:839-851.

Casciola-Rosen LA, Anhalt GJ, Rosen A (1995) DNA-dependent protein kinase is one of a subset of autoantigens specifically cleaved early during apoptosis. J Exp Med 182:1625-1634.

Charriaut-Marlangue C, Margaill I, Represa A, Popovici T, Plotkine M, Ben-Ari Y (1996) Apoptosis and necrosis after reversible focal isch- emia: an in situ DNA fragmentation analysis. J Cereb Blood Flow Metab 16:186-194.

Chen J, Zhu RL, Nakayama M, Kawaguchi K, Jin K, Stetler RA, Simon RP, Graham SH (1996) Expression of the apoptosis-effector gene, Bax, is up-regulated in vulnerable hippocampal CA1 neurons following global ischemia. J Neurochem 67:64-71.

Chen J, Graham SH, Nakayama M, Zhu RL, Jin KL, Stetler RA, Simon RP (1997a) Apoptosis repressor genes bcl-2 and bcl-x-long are expressed in the rat brain following global ischemia. J Cereb Blood Flow Metab 17:1-10.

Chen J, Jin K, Chen M, Pei W, Kawaguchi K, Greenberg DA, Simon RP (1997b) Early detection of DNA strand breaks in the brain after transient focal ischemia: implications for the role of DNA damage in apoptosis and neuronal cell death. J Neurochem 69:232-245.

Chen J, Uchimura K, Stetler RA, Zhu RL, Nakayama M, Jin KL, Graham SH, Simon RP (1998) Transient global ischemia triggers expression of the DNA damage-inducible gene GADD45 in the rat brain. J Cereb Blood Flow Metab 18:646-657.

Deshmukh M, Vasilakos J, Deckwerth TL, Lampe PA, Shivers BD, Johnson Jr EM (1996) Genetic and metabolic status of NGF-deprived sympathetic neurons saved by an inhibitor of ICE family proteases. J Cell Biol 135:1341-1354.

Du Y, Bales KR, Dodel RC, Hamilton-Byrd E, Horn JW, Czilli DL, Simmons LK, Ni B, Paul SM (1997) Activation of a caspase 3-related cysteine protease is required for glutamate-mediated apoptosis of cultured cerebellar granule neurons. Proc Natl Acad Sci USA 94:11657-11662.

Eliasson MJL, Sampei K, Mandir AS, Hurn PD, Traysman RJ, Bao J, Pieper A, Wang ZQ, Dawson TM, Snyder SH, Dawson VL (1997) Poly(ADP-ribose)polymerase gene disruption renders mice resistant to cerebral ischemia. Nat Med 3:1089-1095.

Enari M, Talanian RV, Wong WW, Nagata S (1996) Sequential activation of ICE-like and CPP32-like proteases during Fas-mediated apoptosis. Nature 380:723-726.

Enari M, Sakahira H, Yokoyama H, Okawa K, Iwamatsu A, Nagata S (1998) A caspase-activated DNase that degrades DNA during apoptosis, and its inhibitor ICAD [see comments]. Nature 391:43-50.

Endres M, Wang ZQ, Namura S, Waeber C, Moskowitz MA (1997) Ischemic brain injury is mediated by the activation of poly(ADPribose)polymerase. J Cereb Blood Flow Metab 17:1143-1151.

Fernandes-Alnemri T, Litwack G, Alnemri ES (1994) CPP32, a novel human apoptotic protein with homology to Caenorhabditis elegans cell death protein Ced-3 and mammalian interleukin-1 beta-converting enzyme. J Biol Chem 269:30761-30764.

Fernandes-Alnemri T, Litwack G, Alnemri ES (1995) Mch2, a new member of the apoptotic Ced-3/Ice cysteine protease gene family. Cancer Res 55:2737-2742.

Fernandes-Alnemri T, Armstrong RC, Krebs J, Srinivasula SM, Wang L, Bullrich F, Fritz LC, Trapani JA, Tomaselli KJ, Litwack G, Alnemri ES (1996) In vitro activation of CPP32 and Mch3 by Mch4, a novel human apoptotic cysteine protease containing two FADD-like domains. Proc Natl Acad Sci USA 93:7464-7469.

Gavrieli Y, Sherman Y, Ben-Sasson SA (1992) Identification of programmed cell death in situ via specific labeling of nuclear DNA fragmentation. J Cell Biol 119:493-501.

Gillardon F, Bottiger B, Schmitz B, Zimmermann M, Hossmann KA (1997) Activation of CPP-32 protease in hippocampal neurons following ischemia and epilepsy [In process citation]. Brain Res Mol Brain Res 50:16-22.

Goto K, Ishige A, Sekiguchi K, Iizuka S, Sugimoto A, Yuzurihara M, Aburada M, Hosoya E, Kogure K (1990) Effects of cycloheximide on delayed neuronal death in rat hippocampus. Brain Res 534:299-302.

Han Z, Malik N, Carter T, Reeves WH, Wyche JH, Hendrickson EA (1996) DNA-dependent protein kinase is a target for a CPP32-like apoptotic protease. J Biol Chem 271:25035-25040.

Hara H, Friedlander RM, Gagliardini V, Ayata C, Fink K, Huang Z, Shimizu-Sasamata M, Yuan J, Moskowitz MA (1997) Inhibition of interleukin 1beta converting enzyme family proteases reduces ischemic and excitotoxic neuronal damage. Proc Natl Acad Sci USA 94:2007-2012.

Hugunin M, Quintal LJ, Mankovich JA, Ghayur T (1996) Protease activity of in vitro transcribed and translated Caenorhabditis elegans cell death gene (ced-3) product. J Biol Chem 271:3517-3522.

Juan TS, McNiece IK, Jenkins NA, Gilbert DJ, Copeland NG, Fletcher FA (1996) Molecular characterization of mouse and rat CPP32 beta 
gene encoding a cysteine protease resembling interleukin-1 beta converting enzyme and CED-3. Oncogene 13:749-755.

Kaufmann SH, Desnoyers S, Ottaviano Y, Davidson NE, Poirier GG (1993) Specific proteolytic cleavage of poly(ADP-ribose) polymerase: an early marker of chemotherapy-induced apoptosis. Cancer Res 53:3976-3985.

Keane RW, Srinivasan A, Foster LM, Testa MP, Ord T, Nonner D, Wang HG, Reed JC, Bredesen DE, Kayalar C (1997) Activation of CPP32 during apoptosis of neurons and astrocytes. J Neurosci Res 48:168-180.

Kihara S, Shiraishi T, Nakagawa S, Toda K, Tabuchi K (1994) Visualization of DNA double strand breaks in the gerbil hippocampal CA1 following transient ischemia. Neurosci Lett 175:133-136.

Koistinaho J, Hokfelt T (1997) Altered gene expression in brain ischemia. NeuroReport 8:1-8.

Krajewska M, Wang HG, Krajewski S, Zapata JM, Shabaik A, Gascoyne $\mathrm{R}$, Reed JC (1997) Immunohistochemical analysis of in vivo patterns of expression of CPP32 (Caspase-3), a cell death protease. Cancer Res 57:1605-1613.

Krajewski S, Mai JK, Krajewska M, Sikorska M, Mossakowski MJ, Reed JC (1995) Upregulation of Bax protein levels in neurons following cerebral ischemia. J Neurosci 15:6364-6376.

Kuida K, Zheng TS, Na S, Kuan C, Yang D, Karasuyama H, Rakic P, Flavell RA (1996) Decreased apoptosis in the brain and premature lethality in CPP32-deficient mice. Nature 384:368-372.

Kumar S, Kinoshita M, Noda M, Copeland NG, Jenkins NA (1994) Induction of apoptosis by the mouse Nedd 2 gene, which encodes a protein similar to the product of the Caenorhabditis elegans cell death gene ced-3 and the mammalian IL- 1 beta-converting enzyme. Genes Dev 8:1613-1626.

Lawrence MS, Ho DY, Sun GH, Steinberg GK, Sapolsky RM (1996) Overexpression of Bcl-2 with herpes simplex virus vectors protects CNS neurons against neurological insults in vitro and in vivo. J Neurosci 16:486-496.

Lazebnik YA, Kaufmann SH, Desnoyers S, Poirier GG, Earnshaw WC (1994) Cleavage of poly(ADP-ribose) polymerase by a proteinase with properties like ICE. Nature 371:346-347.

Li Y, Chopp M, Jiang N, Yao F, Zaloga C (1995) Temporal profile of in situ DNA fragmentation after transient middle cerebral artery occlusion in the rat. J Cereb Blood Flow Metab 15:389-397.

Linnik MD, Zahos P, Geschwind MD, Federoff HJ (1995) Expression of bcl-2 from a defective herpes simplex virus-1 vector limits neuronal death in focal cerebral ischemia. Stroke 26:1670-1674.

Liu X, Kim CN, Pohl J, Wang X (1996) Purification and characterization of an interleukin-1beta-converting enzyme family protease that activates cysteine protease P32 (CPP32). J Biol Chem 271:13371-13376.

MacManus JP, Buchan AM, Hill IE, Rasquinha I, Preston E (1993) Global ischemia can cause DNA fragmentation indicative of apoptosis in rat brain. Neurosci Lett 164:89-92.

Martinou JC, Dubois-Dauphin M, Staple JK, Rodriguez I, Frankowski H, Missotten M, Albertini P, Talabot D, Catsicas S, Pietra C, Huarte J (1994) Overexpression of BCL-2 in transgenic mice protects neurons from naturally occurring cell death and experimental ischemia. Neuron 13:1017-1030.

Mashima T, Naito M, Fujita N, Noguchi K, Tsuruo T (1995) Identification of actin as a substrate of ICE and an ICE-like protease and involvement of an ICE-like protease but not ICE in VP-16-induced U937 apoptosis. Biochem Biophys Res Commun 217:1185-1192.

Mashima T, Naito M, Noguchi K, Miller DK, Nicholson DW, Tsuruo T (1997) Actin cleavage by CPP-32/apopain during the development of apoptosis. Oncogene 14:1007-1012.

McConnell KR, Dynan WS, Hardin JA (1997) The DNA-dependent protein kinase catalytic subunit (p460) is cleaved during Fas-mediated apoptosis in Jurkat cells. J Immunol 158:2083-2089.

Miura M, Z hu H, Rotello R, Hartwieg EA, Yuan J (1993) Induction of apoptosis in fibroblasts by IL-1 beta-converting enzyme, a mammalian homolog of the $C$. elegans cell death gene ced-3. Cell 75:653-660.
Ni B, Wu X, Du Y, Su Y, Hamilton-Byrd E, Rockey PK, Rosteck Jr P, Poirier GG, Paul SM (1997) Cloning and expression of a rat brain interleukin- $1 \beta$-converting enzyme (ICE)-related protease (IRP) and its possible role in apoptosis of cultured cerebellar granule neurons. J Neurosci 17:1561-1569.

Nicholson DW, Ali A, Thornberry NA, Vaillancourt JP, Ding CK, Gallant M, Gareau Y, Griffin PR, Labelle M, Lazebnik YA, Munday NA, Raju SM, Smulson ME, Yamin T, Yu V, Miller DK (1995) Identification and inhibition of the ICE/CED-3 protease necessary for mammalian apoptosis. Nature 376:37-43.

Nitatori T, Sato N, Waguri S, Karasawa Y, Araki H, Shibanai K, Kominami E, Uchiyama Y (1995) Delayed neuronal death in the CA1 pyramidal cell layer of the gerbil hippocampus following transient ischemia is apoptosis. J Neurosci 15:1001-1011.

Papas S, Crepel V, Hasboun D, Jorquera I, Chinestra P, Ben-Ari Y (1992) Cycloheximide reduces the effects of anoxic insult in vivo and in vitro. Eur J Neurosci 4:758-765.

Pulsinelli WA, Brierley JB, Plum F (1982) Temporal profile of neuronal damage in a model of transient forebrain ischemia. Ann Neurol 11:491-498.

Rodriguez MS, Wright J, Thompson J, Thomas D, Baleux F, Virelizier JL, Hay RT, Arenzana-Seisdedos F (1996) Identification of lysine residues required for signal-induced ubiquitination and degradation of I kappa B-alpha in vivo. Oncogene 12:2425-2435.

Satoh MS, Lindahl T (1992) Role of poly(ADP-ribose) formation in DNA repair. Nature 356:356-358.

Schulz JB, Weller M, Klockgether T (1996) Potassium deprivationinduced apoptosis of cerebellar granule neurons: a sequential requirement for new mRNA and protein synthesis, ICE-like protease activity, and reactive oxygen species. J Neurosci 16:4696-4706.

Shimazaki K, Ishida A, Kawai N (1994) Increase in bcl-2 oncoprotein and the tolerance to ischemia-induced neuronal death in the gerbil hippocampus. Neurosci Res 20:95-99.

Song Q, Lees-Miller SP, Kumar S, Zhang Z, Chan DW, Smith GC, Jackson SP, Alnemri ES, Litwack G, Khanna KK, Lavin MF (1996) DNA-dependent protein kinase catalytic subunit: a target for an ICElike protease in apoptosis. EMBO J 15:3238-3246.

Song Q, Wei T, Lees-Miller S, Alnemri E, Watters D, Lavin MF (1997) Resistance of actin to cleavage during apoptosis. Proc Natl Acad Sci USA 94:157-162.

Srinivasula SM, Fernandes-Alnemri T, Zangrilli J, Robertson N, Armstrong RC, Wang L, Trapani JA, Tomaselli KJ, Litwack G, Alnemri ES (1996) The Ced-3/interleukin 1beta converting enzyme-like homolog Mch6 and the lamin-cleaving enzyme Mch2alpha are substrates for the apoptotic mediator CPP32. J Biol Chem 271:27099-27106.

Tewari M, Quan LT, O'Rourke K, Desnoyers S, Zeng Z, Beidler DR, Poirier GG, Salvesen GS, Dixit VM (1995) Yama/CPP32 beta, a mammalian homolog of CED-3, is a CrmA-inhibitable protease that cleaves the death substrate poly(ADP-ribose) polymerase. Cell 81:801-809.

Wang X, Zelenski NG, Yang J, Sakai J, Brown MS, Goldstein JL (1996) Cleavage of sterol regulatory element binding proteins (SREBPs) by CPP32 during apoptosis. EMBO J 15:1012-1020.

Xue D, Shaham S, Horvitz HR (1996) The Caenorhabditis elegans celldeath protein CED-3 is a cysteine protease with substrate specificities similar to those of the human CPP32 protease. Genes Dev 10:1073-1083.

Yakovlev AG, Knoblach SM, Fan L, Fox GB, Goodnight R, Faden AI (1997) Activation of cpp32-like caspases contributes to neuronal apoptosis and neurological dysfunction after traumatic brain injury. J Neurosci 17:7415-7424.

Yuan J, Shaham S, Ledoux S, Ellis HM, Horvitz HR (1993) The C. elegans cell death gene ced-3 encodes a protein similar to mammalian interleukin-1 beta-converting enzyme. Cell 75:641-652.

Zhivotovsky B, Burgess DH, Orrenius S (1996) Proteases in apoptosis. Experientia 52:968-978. 